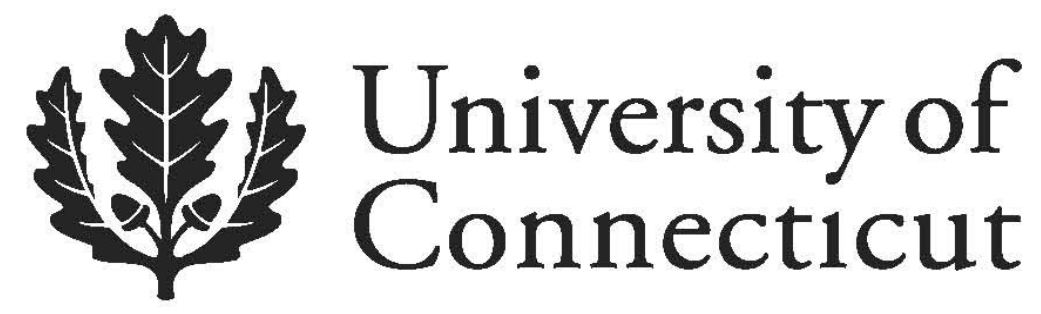

Department of Economics Working Paper Series

\title{
Output Growth and Its Volatility: The Gold Standard through the Great
} Moderation

\author{
WenShwo Fang \\ Feng Chia University \\ Stephen M. Miller \\ University of Nevada, Las Vegas \\ University of Connecticut
}

Working Paper 2012-11

July 2012

341 Mansfield Road, Unit 1063

Storrs, CT 06269-1063

Phone: (860) 486-3022

Fax: (860) 486-4463

http://www.econ.uconn.edu/

This working paper is indexed on RePEc, http://repec.org/ 


\title{
Output Growth and Its Volatility: The Gold Standard through the Great Moderation
}

\author{
WenShwo Fang \\ Department of Economics \\ Feng Chia University \\ 100 WenHwa Road \\ Taichung, TAIWAN \\ wsfang@fcu.edu.tw \\ and \\ Stephen M. Miller* \\ Department of Economics \\ University of Nevada, Las Vegas \\ 4505 Maryland Parkway \\ Las Vegas, Nevada, USA 89154-6005 \\ stephen.miller@unlv.edu
}

\begin{abstract}
:
This study examines the relationship between U.S. output growth and its volatility over the period 1875:Q1 to 2008:Q2. We examine the data for outliers and apply corrections when found. Next, we search for possible effects of structural breaks in the growth rate and its volatility. In so doing, we employ autoregressive generalized conditional heteroskedasticity and autoregressive exponential general conditional heteroskedasticity specifications of the process describing output growth rate and its volatility with and without structural breaks in the mean and volatility processes. We discover one break in the mean process - 1936:Q2 - and three breaks in the volatility process - 1916:Q4, 1950:Q3, and 1983:Q4 (or 1984:Q3). After accommodating the breaks in the mean and volatility processes, the integrated generalized autoregressive conditional heteroskedasticity effect proves spurious. Finally, our data analyses and empirical results suggest that higher output-growth volatility stimulates output growth and that higher output growth reduces its volatility. Moreover, the evidence shows that the time-varying variance falls sharply once we incorporate the three structural breaks in the unconditional variance of output.
\end{abstract}

Keywords: $\quad$ economic growth and volatility, structural change, IGARCH

JEL classification: C32; E32; O40

* Corresponding author 


\section{Introduction}

Researchers occasionally consider the possible structural changes in the duration of recessions and expansions. For example, Diebold and Rudebusch (1992), Cover and Pecorino (2005), and Young and Du (2008) all investigate the possibility of break points in the business cycle, examining the duration of recessions and expansions. Diebold and Rudebusch (1992) and Cover and Pecorino (2005) use the NBER reference cycle data in their analysis. Young and Du (2008) also examine detrended real GDP growth in addition to the NBER reference cycles.

Researchers more frequently explore the possible structural change in the volatility of real GDP growth. For example, Kim and Nelson (1999), McConnell and Perez-Quiros (2000), Blanchard and Simon (2001), and Ahmed et al. (2004), among others, document a structural change in the volatility of U.S. GDP growth, finding a rather dramatic reduction in GDP volatility that some have labeled the Great Moderation. Stock and Watson (2003), Bhar and Hamori (2003), Mills and Wang (2003), and Summers (2005) show a structural break in the volatility decline of the output growth rate for Japan and other G7 countries, although the break occurs at different times.

Researchers now most frequently employ an autoregressive model for the mean equation of real GDP growth and some form of a generalized autoregressive conditional heteroskedasticity (GARCH) modeling strategy to examine the volatility of real GDP growth. Most such studies, however, assume a stable GARCH or exponential GARCH (EGARCH) process, capturing the movement in volatility. The neglect of potential structural breaks in the unconditional or conditional variances of output growth leads to high persistence in the conditional volatility or integrated GARCH (IGARCH). That is, typically all persistence measures fall close to one.

The evidence of a structural change in output growth volatility combined with finding high persistence in conditional volatility motivates us to revisit the issue of conditional volatility in real 
GDP growth rates for the US, using a much longer time-series data set - 1875:Q1 to 2008:Q2. ${ }^{1}$ We report that three structural breaks exist in the variance resulting in high volatility persistence 1916:Q4, 1950:Q3, and 1983:Q4 (or 1982:Q3). This issue is well known the theoretical level; ${ }^{2}$ but, the only empirical examination for the U.S. appears in Fang and Miller (2008). This paper contributes to the literature by providing some new evidence from the US that focuses on a longer time horizon extending back to the last quarter of the $19^{\text {th }}$ century. First, excess kurtosis in the growth rate drops substantially or disappears in GARCH or EGARCH models, once we modify outliers in the data set. Non-normally distributed residuals may emerge by not modeling the extraordinary change in the growth series. Second, the IGARCH effect or high volatility persistence remains, when we introduce one structural break in the mean equation. Third, the time-varying variance falls sharply, only when we incorporate the three breaks in the variance equation. The IGARCH effect proves spurious due to nonstationary variance of output growth. Fourth, the $\operatorname{GARCH}(1,1)$ model finds significant effects of our more correct specification of output volatility on output growth or of output growth on its volatility.

Using U.S. quarterly real GDP data, Fang and Miller (2008) report that the long-term

\footnotetext{
${ }^{1}$ The sample ends at the beginning of the financial crisis and the Great Recession, which may emerge as another break point in output growth and its volatility.

${ }^{2}$ Diebold (1986) first argues that structural changes may confound persistence estimation in GARCH models. He notes that Engle and Bollerslev's (1986) integrated GARCH (IGARCH) may result from instability of the constant term of the conditional variance (i.e., nonstationarity of the unconditional variance). Neglecting such changes can generate spuriously measured persistence with the sum of the estimated autoregressive parameters of the conditional variance heavily biased towards one. Lamoureux and Lastrapes (1990) provide confirming evidence that ignoring discrete shifts in the unconditional variance, the misspecification of the GARCH model can bias upward GARCH estimates of persistence in variance. Including dummy variables to account for such shifts diminishes the degree of GARCH persistence. More recently, Mikosch and Stărică (2004) prove that the IGARCH model makes sense when non-stationary data reflect changes in the unconditional variance. Hillebrand (2005) shows that in the presence of neglected parameter change-points, even a single deterministic change-point can cause GARCH to measure volatility persistence inappropriately. Alternatively, Hamilton and Susmel (1994) and Kim et al. (1998) suggest that the long-run variance dynamics may include regime shifts, but within a given regime, it may follow a GARCH process. Kim and Nelson (1999), Bhar and Hamori (2003), Mills and Wang (2003), and Summers (2005) apply this approach of Markov switching heteroskedasticity with two states to examine the volatility of real GDP growth and identify structural changes.
} 
growth rate of output does not shift and its variance declines. This combination may imply immediately a weak relationship between growth and volatility. ${ }^{3}$ In contrast, for our much longer time-series data set from 1875:Q1 to 2008:Q2 rather than the post-WWII sample of Fang and Miler (2008), we find that structural changes emerge in the variance as well as the mean of the real GDP growth rate identified by the multiple structural change test of Bai and Perron $(1998,2003)$. If the long-term mean growth rate fell substantially, which we find, the implication of the Great Moderation for the relationship between output growth and its volatility is not straightforward and requires model-based calculations.

The rest of the paper unfolds as follows. Section 2 discusses the data, detects and corrects outliers, models the unstable GARCH process of output growth volatility, and identifies the break dates in the mean and the conditional variance. Section 3 presents empirical results with changes in the mean and the variance and identifies two areas of misspecification of the GARCH modeling of output growth volatility. Section 4 considers evidence on the relationship between the output growth rate and its volatility. Finally, Section 5 concludes.

\section{Data Analysis and Modeling}

Output growth rates $\left(y_{t}\right)$ equal the percentage change in the logarithm of seasonally adjusted quarterly real GDP $\left(Y_{t}\right)$ with base year 2000 over the period 1875:Q1 to 2008:Q2. That is, we create the quarterly real GDP series, involving one splice. The original data come from Balke and Gordon (1986) from 1875:Q1 to 1983:Q4 (base year = 1972) and the US Bureau of Economic Analysis from 1947:Q1 to 2008:Q2 (base year = 2000). We splice the 1875:Q1 to 1983:Q4 real GDP series to the 1947:Q1 to 2008:Q2 real GDP series in 1947:Q1, measured in 2000 prices.

\footnotetext{
${ }^{3}$ Stock and Watson (2003) interpret the moderation in output volatility with no change in the mean growth rate as shorter recessions and longer expansions in the US, linking to the literature on durations of recessions and expansions..
} 


\section{Descriptive Statistics}

Table 1 reports descriptive statistics for the growth rate of the spliced quarterly real GDP. The US experiences a mean growth rate of 0.82 percent for the full 134-year sample with the highest rate of 7.96 in 1879:Q4 and the lowest rate of -8.76 in 1893:Q3. Output volatility, represented by the standard deviation, equals 2.24. Under the assumptions of normality, standard measures of skewness and kurtosis possess asymptotic distributions of $\mathrm{N}(0,6 / \mathrm{T})$ and $\mathrm{N}(0,24 / \mathrm{T})$, respectively, where $\mathrm{T}(=533)$ equals the sample size. The skewness statistic displays an asymmetric distribution characterized by negative skewness, meaning that in the sample period, a greater probability exists of large decreases in real GDP growth than large increases. The kurtosis statistic exhibits leptokurticity with fat tails, meaning that extreme changes occur more frequently with a higher kurtosis. The Jarque-Bera test rejects normality. Ljung-Box $Q$ and $Q^{2}$ statistics test for autocorrelation up to nine lags. The Ljung-Box statistics ( $L B Q$ ) indicate autocorrelation in the growth rates, while the Ljung-Box statistics for squared rates $\left(L B Q^{2}\right)$ suggest time-varying variance in the series. Autocorrelation and heteroskedasticity suggest ARMA processes for the mean and the variance equations to capture the dynamic structure and to generate white-noise residuals.

\section{Autoregressive Model of Output Growth Rate}

Table 1 also reports the results of the AR model constructed for the growth rate series. Based on the Schwarz Bayesian Criterion (SBC), four lags, an AR(4) process, prove adequate to capture growth dynamics and produce uncorrelated residuals. That is, the mean growth rate equation equals the following:

$$
y_{t}=a_{0}+\sum_{i=1}^{4} a_{i} y_{t-i}+\varepsilon_{t},
$$

where the growth rate $y_{t} \equiv 100 \times\left(\ln Y_{t}-\ln Y_{t-1}\right), \ln Y_{t}$ equals the natural logarithm of real GDP, 
and $\varepsilon_{t}$ equals the serially uncorrelated error term.

The AR(4) model proves problematic in several areas. First, we reject normality of the error term with significant skewness and kurtosis. Second, the significant Ljung-Box Q-statistics for squared rates indicate time-varying variance in the series, although the insignificant Ljung-Box Q-statistics suggest no autocorrelation. We expect to resolve these two issues of misspecification by modeling outliers and changes in the mean and the variance equations. That is, the likelihood of biasing the estimated volatility persistence parameters toward one and the skewness and leptokurtosis in the distribution of output growth should vanish after adjustment of the GARCH model with various changes.

\section{Outlier Detection and Correction}

Economic and financial time series frequently include outliers. ${ }^{4}$ An outlier observation appears inconsistent with other observations in the growth rates. To the best of our knowledge, however, researchers typically overlook their existence and effect when modeling output growth and its volatility. ${ }^{5}$ The combined task of detecting outliers and correcting them faces similar problems to the lag-length selection process in time-series modeling. Too many outliers in a data series deteriorate the quality of that data; too few (i.e., correcting too many outliers) may prevent the capture of important structural changes in the data series.

Table A1 in the Appendix identifies the outliers in the growth rate of real GNP, using the

\footnotetext{
${ }^{4}$ Balke and Fomby (1994) analyze fifteen post-World War II U.S. macroeconomic time series using the outlier identification procedure based on Tsay (1988) and find that outliers may prove important for U.S. macroeconomic data, and such aberrant observations may lead to large ARCH test statistics. van Dijk, Franses, and Lucas (1999) demonstrate that neglecting additive outliers frequently leads to a rejection of the null hypothesis of homoskedasticity, when it is in fact true. Tolvi (2001) and Charles and Darné (2006), however, show another possibility. That is, outliers can hide the ARCH tests of the series. After correcting the data for outliers, returns series sometimes display strong evidence of ARCH. Franses and Ghijsels (1999) and Charles and Darné (2005, 2006) apply the method of Chen and Liu (1993) to correct for additive outlier and show that correcting for additive outliers reduces excess kurtosis in GARCH models and improves forecasts of stock market volatility.

${ }^{5}$ Fang and Miller (2008) provide an exception. They develop the method that we generally follow in this paper.
} 
following selection criterion: $\mid y_{t}-$ Mean $\mid>k \cdot S D$, where $k$ measures the stringency imposed on outlier detection. When $k=4$, we identify only one outlier and when $k=2$, we indentify 45 outliers. Finally, with $k=3$, we find 11 outliers. We focus on the results for $k=3$. Of the 11 outliers, three represent high growth rates, while eight represent low (negative) growth rates.

We apply the Franses and Ghijsels (1999) method to correct additive outliers in GARCH models. In the correction process, we, first, estimate the AR(4)-GARCH(1,1) model for the growth rate series and replace the observed growth rates with outlier-corrected values.

Table 2 reports descriptive statistics for the outlier-corrected growth rate. Comparing Table 2 to Table 1, we corrected eight negative outliers but only three positive outliers and the skewness statistic moves form a significant negative value in Table 1 to an insignificant positive value in Table 2. Nonetheless, even though the test statistics both decrease in value, we still observe significant kurtosis and non-normality in the outlier-corrected growth rate series.

Table 2 also reports the results of estimating the AR(4) model for the growth rate of real GNP assuming a homoskedastic error process. We note that the error process does not exhibit skewness or kurtosis and we cannot reject the null hypothesis of a normal error structure. We do find evidence of heteroskedastic errors, which leads to our analysis of a GRACH process for the error process in the $\mathrm{AR}(4)$ mean equation.

\section{Identifying Structural Change}

Using the outlier-corrected data, we look for structural changes in the volatility for GDP growth in sequential steps. First, we estimate equation (1) allowing for the possibility of structural breaks in its intercept and slope coefficients. Specifically, we use the statistical techniques of Bai and Perron $(1998,2003)$ to estimate multiple break dates without prior knowledge of when those breaks occur. After finding any breaks in the mean of $y_{t}$, we use that model specification to obtain series of 
estimated residuals, $\hat{\varepsilon}_{t}$. Second, we search for breaks in the variance by testing for parameter constancy in the conditional mean of the absolute value of the residuals $\hat{\varepsilon}_{t}$ as shown in Cecchetti et al. (2005) and Herrera and Pesavento (2005).

Bai and Perron $(1998,2003)$ propose several tests for multiple breaks. We adopt one procedure and sequentially test the hypothesis of $\mathrm{m}$ breaks versus $\mathrm{m}+1$ breaks using $\sup F(m+1 \mid m)$ statistics, which detects the presence of $m+1$ breaks conditional on finding $m$ breaks and the supremum comes from all possible partitions of the data for the number of breaks tested. In the application of the test, we search for up to five breaks. If we reject the null of no break at the 5-percent significance level, we, then, estimate the break date using least squares, to divide the sample into two subsamples according to the estimated break date, and to perform a test of parameter constancy for both subsamples. We repeat this process by sequentially increasing $m$ until we fail to reject the hypothesis of no additional structural change. In the process, rejecting $m$ breaks favors a model with $m+1$ breaks, if the overall minimal value of the sum of squared residuals over all the segments, including an additional break, falls sufficiently below the sum of squared residuals from the model with $m$ breaks. The break dates selected include the ones associated with this overall minimum. We search for multiple breaks in the series of output growth using the GAUSS code made available by Bai and Perron (2003).

Table 3 displays the results of testing for breaks in the mean and the variance, their critical values at the 5-percent significance level (in brackets). Pure and partial structural breaks refer to the situations where the test permits all coefficients to change (pure) and only the intercept coefficient to change (partial). When testing for pure structural breaks, the value of the $\sup F(5 \mid 0)$ test proves significant for $m=5$, suggesting the existence of at least one break in the growth rate series. The sequential $\sup F(m+1 \mid m)$ exhibits significance only for $m=1$. That is, given the 
existence of one break, sup $F(2 \mid 1)=16.6217$ suggests that only one break exists. The break date occurs at 1936:Q2 with 95\% confidence interval [1912:Q3 to 1962:Q2]. The procedure also identifies three structural breaks in the variance of growth rates at 1916:Q4, 1950:Q3, and 1982:Q4 with 95-percent confidence intervals [1905:Q4 to 1922:Q4], [1948:Q4 to 1956:Q1], and [1982:Q2 to 1990:Q3]. Thus, three structural changes in the GARCH process govern volatility.

Considering partial structural breaks leads to the following conclusions. First, we do not find a break in the intercept of the mean equation. That is, the structural break in the mean equation reflects entirely shifts in the slope coefficients of the AR(4) process, that is, coefficients of the second, third, and fourth lags (see Tables 5 and 6). We still identify three structural breaks in the variance at 1916:Q4, 1950:Q3 and 1982:Q3 with 95-percent confidence ranges of [1906:Q1 to 1920:Q4], [1949:Q2 to 1956:Q1], and [1979:Q3 to 1990:Q1].

Table 4 reports the structural stability tests for the unconditional variance as well as the mean of the growth rate by splitting the sample into sub-periods according to the break dates. Panels A and B report the pure and partial structural breaks, respectively. For the unconditional mean, a $t$-statistic tests for the equality of means under unequal variances for two different samples, while a variance-ratio statistic tests for the equality of the unconditional variances.

In Panel A, the mean growth rates in each sub-sample do not differ significantly, since the t-statistic cannot reject the null hypothesis of equal means. The structural break identified in the mean for the pure structural break test occurs only in the slope coefficients and not the intercept (see Tables 5 and 6). The standard deviations significantly differ between all four sub-periods. The standard deviation rises from 1.5877 between 1876:Q1 and 1916:Q4 to 2.4199 between 1917:Q1 to 1950:Q3 and then falls to 1.1303 between 1950:Q4 to 1983:Q4 before falling further during the Great Moderation to 0.5232 between 1982:Q4 to 2008:Q2. In panel B, no structural break exists 
for the mean equation. The standard deviations, once again, significantly differ between all four sub-periods. The standard deviation rises from 1.5877 between 1876:Q1 and 1916:Q4 to 2.4199 between 1917:Q1 to 1950:Q3 and then falls to 1.1333 between 1950:Q4 to 1982:Q3 before falling further during the Great Moderation to 0.5648 between 1982:Q4 to 2008:Q2.

Figure 1 plots the observed real GDP growth rate. The eye can catch the decrease in the volatility around 1950 and then another decrease around 1982. The increase in volatility documented around 1916 does not appear so obvious.

GARCH Modeling of Output Volatility

To consider the effect of the Great Moderation on the volatility persistence of output growth in GARCH specifications, we include dummy variables in the conditional variance equation, which equal unity from the break date forward, zero otherwise, in the GARCH and EGARCH processes, respectively, as follows:

$$
\begin{aligned}
& \sigma_{t}^{2}=\alpha_{0}+\alpha_{1} \varepsilon_{t-1}^{2}+\beta_{1} \sigma_{t-1}^{2}+\gamma_{1} D_{1}+\gamma_{2} D_{2}+\gamma_{3} D_{3}, \\
& \log \sigma_{t}^{2}=\alpha_{0}+\alpha_{1} \frac{\left|\varepsilon_{t-1}\right|}{\sigma_{t-1}}+\alpha_{2} \frac{\varepsilon_{t-1}}{\sigma_{t-1}}+\beta_{1} \log \sigma_{t-1}^{2}+\gamma_{1} D_{1}+\gamma_{2} D_{2}+\gamma_{3} D_{3},
\end{aligned}
$$

where $D_{1}=1$ for $t>1916: Q 3$, 0, otherwise; $D_{2}=1$ for $t>1950: Q 2,0$, otherwise; and $D_{3}=1$ for $t>1983$ : Q3 , 0, otherwise. The dummy variables accommodate the extraordinary changes. Since the volatility first increases and then declines twice, we expect a significant positive estimate for $\gamma_{1}$ and significant negative estimates for $\gamma_{2}$ and $\gamma_{3}$ to capture the break in the variance process. In equation (3), asymmetry in the response exists if $\alpha_{2} \neq 0$. Moreover, negative (positive) shocks generate higher volatility than positive (negative) shocks of the same magnitude when $\alpha_{2}<0$ $\left(\alpha_{2}>0\right)$.

Although the data do not suggest a significant change in the mean of the growth rate of real 
GNP, we do find a significant change in the structure of the mean equation, that is, the coefficients of the AR(4) process shift in 1936:Q2. To accommodate the structural change in the mean equation, we specify that equation as follows:

$$
y_{t}=a_{0}+\sum_{i=1}^{4} a_{i} y_{t-i}+d_{0} D+\sum_{i=1}^{4} d_{i} D y_{t-i}+\varepsilon_{t},
$$

where we define $b_{i}=a_{i}+d_{i}, i=0,1,2,3,4$, and $D=1$ for $t>1936: Q 1$, 0 , otherwise.

Tables 5 and 6 report the results of estimating the mean equation in an AR(4) process and its volatility as a GARCH(1,1). Column 1 reports the results for the raw, uncorrected data whereas column 2 reports the results for the outlier corrected data, where we replace 11 quarterly growth rates with adjusted values. Columns 3 and 4 lists the results for the outlier corrected data and incorporating the mean structural shift dummy variable (column 3) and then both the mean and variance shift dummy variables (column 4).

Estimating the mean model with a GARCH(1,1) specification for the error term (column 1) leads to an IGARCH outcome with significant skewness and kurtosis as well as non-normality. When we use the outlier-corrected data (column 2), we still experience the IGARCH outcome but the significant skewness and kurtosis disappear and normality appears. The IGARCH remains when we also accommodate the structural shift in the mean equation (column 3).

Including both the structural shifts in the mean and the volatility equations (column 4) eliminates the IGARCH. The coefficients of the structural dummy variables in the volatility equation (i.e., $\gamma \mathrm{s}$ ) prove significant. We see a significant increase in the volatility between the 1876:Q1 to 1916:Q4 and the 1917:Q1 to 1950:Q3 periods. Then we find significant decreases in volatility between the 1917:Q1 to 1950:Q3 and 1950:Q4 to 1983:Q4 periods and between the 1950:Q4 to 1983:Q4 and the 1984:1 to 2008:Q2 periods. Further, the Ljung-Box Q-statistics of the standardized residuals and the squared standardized residuals show no evidence of autocorrelation 
and heteroskedasticity, providing support for the specification of the GARCH or the EGARCH. The significant LR statistic at the 5-percent level indicates no IGARCH effect.

The results of the symmetric or asymmetric GARCH models suggest that the time-varying variance in the growth rate may reflect major structural changes in the implementation of monetary policy, although other rationalizations may make sense as well. The first period between 1876:Q1 to 1916:Q4 reflects the gold standard and that ended with the start of WWI. The second sub-period between 1917:Q1 to 1950:Q3 include the two World Wars and the inter-War period where countries sought unsuccessfully to return to the gold standard. The third sub-period between 1950:Q4 to 1983:Q4 begins near the Treasury Federal Reserve Accord whereby the Federal Reserve System received more independence in the conduct of monetary policy. Finally, the last period, called the Great Moderation, begins shortly after the drastic reduction in deflation engineered by the Volker Federal Reserve though early 2008.

In sum, previous studies assume implicitly that a stable GARCH process governs conditional growth volatility. The neglect of the structural breaks in the variance implies misspecification of the conditional variance. This leads to the conclusion of a significant IGARCH effect. Moreover, taking no account of possible outliers and breaks in the growth rates entails excess kurtosis, and, thus, a significant Jarque-Bera test. Fang and Miller (2008) pioneered the adjustment for outliers and the inclusion of structural breaks in the volatility of the output growth rate, leading to the disappearance of the IGARCH effect. In fact, they found for post WWII data that the proper specification reduced to a simple ARCH model. We extend the method of Fang and Miller (2008) to a longer data series and find four periods of different volatility identified by break points in 1916:Q4, 1950:Q3, and 1983:Q3. Our findings still imply an AR-GARCH or AR-EGARCH specification. 


\section{Relationship between Output Volatility and Economic Growth}

The prior section considers the appropriate time-series specification of the volatility of the growth rate of real GDP. A number of authors examine the issue of how this volatility affects the growth rate of GDP. That is, does the decreased real GDP growth rate volatility cause a higher or lower real GDP growth rate? For example, applying a GARCH in mean (GARCH-M) model (Engle et al., 1987) and using post-war real quarterly GDP data, Henry and Olekalns (2002) discover a significant asymmetric GARCH effect and a negative link between volatility and real GDP growth for the U.S. without consideration of structural shift in the volatility process. In contrast, Fang and Miller (2008) find a weak GARCH effect and no link between volatility and growth for the U.S. with a structural break in the volatility process. This section pursues this question with our more appropriate time-series specification of the real GDP growth rate volatility. This issue is important because structural break in variance biases upward GARCH estimates of persistence in variance and, thus, vitiates the use of GARCH to estimate its mean effect.

In this section, the mean growth rate shown in equation (4) translates into the following:

$$
y_{t}=a_{0}+\sum_{i=1}^{4} a_{i} y_{t-i}+d_{0} D+\sum_{i=1}^{4} d_{i} D y_{t-i}+\lambda \sigma_{t}+\varepsilon_{t}
$$

where $\sigma_{t}$ equals the standard deviation of the conditional variance, $\sigma_{t}^{2}, \lambda$ measures the volatility effect in the mean, and $D=1$ for $t>1936: Q 1,0$, otherwise.

Alternative theoretical models imply different results -- negative, positive, or independent relationships between output growth volatility and output growth. For example, the misperceptions theory, proposed originally by Friedman (1968), Phelps (1968), and Lucas (1972), argues that output fluctuates around its natural rate, reflecting price misperceptions due to monetary shocks. The long-run growth rate of potential output, however, reflects technology and other real factors. The standard dichotomy in macroeconomics implies no relationship between 
output volatility and its growth rate (i.e., $\lambda=0$ ). Martin and Rogers $(1997,2000)$ argue that learning-by-doing generates growth whereby production complements productivity-improving activities and stabilization policy can positively affect human capital accumulation and growth. One natural conclusion, therefore, implies a negative relationship between output growth volatility and growth (i.e., $\lambda<0$ ). In contrast, Black (1987) argues that high output volatility and high growth coexist. According to Blackburn (1999), a relative increase in the volatility of shocks increases the pace of knowledge accumulation and, hence, growth, implying a positive relation between output growth volatility and growth (i.e., $\lambda>0$ ).

More recently, Fountas et al. (2006) consider the possibility of a two-way relationship between output growth and its volatility. The authors first estimate a bivariate GARCH specification of output growth and inflation. And then they recover the means and conditional variances for output growth and inflation to run a second-stage four-variable vector-autoregressive model to conduct Granger-causality tests. Using G7 examples, they find that output growth volatility positively affects output growth in all the seven countries, except Japan, and output growth negatively affects output growth volatility in Japan, Germany, and the U.S. and a zero effect in the rest of the countries. That is, a bi-directional causality between output growth and its volatility exists in Germany and the U.S., and one-way causality in Japan and the other four countries.

In a GARCH-M model, if output growth partly determines its volatility but is excluded in the variance equation, then the conditional variance equation is misspecified and GARCH-M estimates are not consistent (see Pagan and Ullah, 1988). Fountas and Karanasos (2006) and Fang and Miller (2008) develop a structural specification that incorporates the contemporaneous conditional volatility into the mean equation for output growth and lagged output growth into the 
conditional variance equation in their GARCH-M models. Contrary to Fountas et al. (2006), Fountas and Karanasos (2006) find, using annual industrial production data from 1860 to 1999 , that the output growth rate volatility exhibits no effect on the growth rate, but the output growth rate affects its volatility negatively in the US. Similarly, Fang and Miller (2008), using quarterly post-WWII US data on real GDP growth, report that output growth rate volatility does not affect output growth, but that output growth does negatively affect its volatility.

To avoid the GARCH-M model suffering from an endogeneity bias, we augment the variance equations (4) and (5) to include lagged output growth, respectively, as follows:

$$
\begin{gathered}
\sigma_{t}^{2}=\alpha_{0}+\alpha_{1} \varepsilon_{t-1}^{2}+\beta_{1} \sigma_{t-1}^{2}+\theta y_{t-1}+\gamma_{1} D_{1}+\gamma_{2} D_{2}+\gamma_{3} D_{3}, \\
\begin{aligned}
\log \sigma_{t}^{2}=\alpha_{0}+\alpha_{1} \frac{\left|\varepsilon_{t-1}\right|}{\sigma_{t-1}}+ & \alpha_{2} \frac{\varepsilon_{t-1}}{\sigma_{t-1}}+\beta_{1} \log \sigma_{t-1}^{2}+\theta y_{t-1} \\
& +\gamma_{1} D_{1}+\gamma_{2} D_{2}+\gamma_{3} D_{3},
\end{aligned}
\end{gathered}
$$

where $\theta$ measures the level effect of the output growth in variance. To the best of our knowledge, no economic theory models explicitly the effect of output growth on its volatility. Theoretically, the sign of $\theta$ is unknown. Intuitively, Fountas et al. (2006) argue that either a negative or a positive relation may occur. That is, an increase in output growth leads to more inflation, if both the Friedman (1977) hypothesis and the Taylor (1979) effect hold, then higher inflation raises inflation volatility and higher inflation volatility trades off with output volatility. Thus, output growth and its volatility are negatively related (i.e., $\theta<0$ ). Ungar and Zilberfarb (1993), however, show that higher inflation reduces inflation volatility, and thus a positive relation (i.e., $\theta>0$ ) may also occur.

Tables 5 and 6 report the GARCH and EGARCH results, where we include the structural shift in the mean equations well as the three-time structural break in the variance process. Columns 5 and 6 report the results for the level effect in the variance equation only and the GARCH-M 
effect in the mean equation only, respectively. Column 7 lists the results for both the level effect in the variance equation and the GARCH-M effect in the mean equation simultaneously. Whether separate or together, Table 5 shows that the coefficient of the level effect in the variance equation and the GARCH-M effect in the mean equation prove significantly negative and positive, respectively, in the GARCH model. In sum, a higher variability leads to a higher growth rate and a higher growth rate leads to a lower variance. These findings match our period-by-period calculations of the mean values. That is, the second sub-period exhibited a higher variability and growth when compared to the first sub-period. Then the third and fourth sub-periods experienced lower variability and growth than their preceding sub-periods. These results, however, differ from those of Fountas and Karanasos (2006) and Fang and Miller (2008). Fountas and Karanasos (2006) use a long-sample of over 100 years, but they use annual data on industrial production. Fang and Miller (2008) do use quarterly data, but only for the post-WWII period.

Table 6 shows that the level and GARCH-M effects in the variance and mean equations, respectively, completely disappear in the EGARCH specification. In addition, the effect of innovations on the mean equation exert different effects on the logarithm of the standard deviation, where negative shocks exhibit a larger effect than positive shocks. That is, we find significant evidence of asymmetric effects. Moreover, the function value suggests that the AR-EGRACH specification dominates the AR-GARCH specification. As a consequence, our results suggest that prior findings of feedback between the volatility of the output growth rate and the output growth rate and vice versa may occur because researchers did not accommodate asymmetric responses in an EGARCH model.

\section{Conclusion}

This paper examines the effect of the Great Moderation on the relationship between quarterly real 
GDP growth rate and its volatility in the U.S. over the period 1875:Q1 to 2008:Q2. First, we inspect the data for outliers and apply appropriate corrections on the outliers discovered. Second, we perform tests for structural breaks in the growth rate and its volatility. In so doing, we employ AR-GARCH and AR-EGARCH specifications of the process describing output growth rate and its volatility with and without structural breaks in the mean and volatility processes. Third, we identify one break in the mean process - 1936:Q2 - and three breaks in the volatility process 1916:Q4, 1950:Q3, and 1983:Q4 (or 1984:Q3). After accommodating the breaks in the mean and volatility processes, the IGARCH effect proves spurious. Finally, our data analyses and empirical results suggest that output growth volatility positively affects output growth and that higher output growth negatively affects its volatility. Moreover, the evidence shows that the time-varying variance falls sharply once we incorporate the three structural breaks in the unconditional variance of output.

The independence between the output growth and its volatility needs careful interpretation. Endogenous growth theory, for example, does not imply any importance for the second moment. Blackburn and Galindev (2003) and Blackburn and Pelloni (2004) model the link between the mean and variance of the output growth rate explicitly. Different mechanisms of endogenous technological change and nominal or real shocks can lead to positive or negative relationship between growth and volatility. In his model, Blackburn (1999) shows for a linear endogenous learning function, the effect of the output growth-rate volatility on the output growth rate equals zero. A concave (convex) learning function generates a negative (positive) effect. That is, an independent relationship may exist with or without the Great Moderation. The disagreements between published findings highlights the sensitivity of the results to the country considered, the time period examined, the frequency of the data, and the methodology employed. This apparent 
inconclusiveness warrants further investigation of the relationship between growth and its volatility. Nevertheless, we conclude with a cautionary note that failure to model structural breaks in the volatility of output growth and/or failure to model volatility asymmetries may lead researchers to conclude falsely that output volatility affects output growth. 


\section{References}

Ahmed, S., Levin, A. and Wilson, B.A. (2004) Recent U.S. macroeconomic stability: Good policies, good practices, or good luck? Review of Economics and Statistics 86, 824-832.

Bai, J. and Perron, P. (1998) Estimating and testing linear models with multiple structural changes, Econometrica 66, 47-78.

Bai, J. and Perron, P. (2003) Computation and analysis of multiple structural change models, Journal of Applied Econometrics 18, 1-22.

Balke, N. and Fomby, T. B. (1994) Large shocks, small shocks, and economic fluctuations: Outliers in macroeconomic time series, Journal of Applied Econometrics 9, 181-200.

Bhar, R. and Hamori, S. (2003) Alternative characterization of the volatility in the growth rate of real GDP, Japan and the World Economy 15, 223-231.

Black, F. (1987) Business Cycles and Equilibrium, Basil Blackwell, New York.

Blackburn, K. (1999) Can stabilization policy reduce long-run growth? Economic Journal 109, 67-77.

Blackburn, K. and Galindev, R. (2003) Growth, volatility and learning, Economics Letters 79, 417-421.

Blackburn, K. and Pelloni A. (2004) On the relationship between growth and volatility, Economics Letters 83, 123-127.

Blanchard, O. and Simon, J. (2001) The long and large decline in U.S. output volatility, Brookings Papers on Economic Activity 32, 135-174.

Charles, A. and Darné, O. (2005) Outliers and GARCH models in financial data, Economics Letters 86, 347-352.

Charles, A. and Darné, O. (2006) Large shocks and the September $11^{\text {th }}$ terrorist attacks on international stock markets, Economic Modelling 23, 683-698.

Chen, C. and Liu, L. (1993) Joint estimation of model parameters and outlier effects in time series, Journal of the American Statistical Association, 88, 284-297.

Cecchetti, S. G., Flores-Lagunes, A. and Krause, S. (2005) Assessing the sources of changes in the volatility of real growth, in The Changing Nature of the Business Cycle, ed. C. Kent and D. Norman, Reserve Bank of Australia, 115-138.

Cover, J. P., Pecorino, P., 2005. The length of US business expansions: when did the break in the data occur? Journal of Macroeconomics 27, 452-471. 
Diebold, F. X. (1986) Comments on modelling the persistence of conditional variance, Econometric Reviews 5, 51-56.

Diebold, F. X., and Rudebusch, G. D., (1992). Have postwar economic fluctuations been stabilized? American Economic Review 92, 993-1005.

Engle, R. F. and Bollerslev, T. (1986) Modelling the persistence of conditional variance, Econometric Reviews 5, 1-50.

Engle, R. F., Lilien, D. and Robins, R. (1987) Estimating time varying risk premia in the term structure: The ARCH-M model, Econometrica 55, 391-407.

Fang, W. and Miller, S. M. (2008) The Great Moderation and the relationship between output growth and its volatility, Southern Economic Journal 74, 819-838.

Fountas, S. and Karanasos, M. (2006) The relationship between economic growth and real uncertainty in the G3, Economic Modelling 23, 638-647.

Fountas, S., Karanasos, M., and Kim, J. (2006) Inflation uncertainty, output growth uncertainty and macroeconomic performance, Oxford Bulletin of Economics and Statistics 68, 319-343.

Franses, P. H. and Ghijsels, H. (1999) Additive outliers, GARCH and forecasting volatility, International Journal of Forecasting 15, 1-9.

Friedman, M. (1968) The role of monetary policy, American Economic Review 58, 1-17.

Friedman, M. (1977) Nobel lecture: inflation and unemployment, Journal of Political Economy 85, 451-472.

Hamilton, J. D. and Susmel, R. (1994) Autoregressive conditional heteroskedasticity and changes in regime, Journal of Econometrics 64, 307-333.

Henry, O. T. and Olekalns, N. (2002) The effect of recessions on the relationship between output variability and growth, Southern Economic Journal 68, 683-692.

Herrera, A. M. and Pesavento, E. (2005) The decline in U.S. output volatility: structural changes and inventory investment, Journal of Business and Economic Statistics 23, 462-472.

Hillebrand, E. (2005) Neglecting parameter changes in GARCH models, Journal of Econometrics 129, 121-138.

Kim, C. J. and Nelson, C. R. (1999) Has the U.S. economy become more stable? A Bayesian approach based on a Markov-Switching model of the business cycle, Review of Economics and Statistics 81, 1-10. 
Kim, C. J., Nelson, C. R. and Startz, R. (1998) Testing for mean reversion in heteroskedastic data based on Gibbs sampling augmented randomization, Journal of Empirical Finance 5, 131-154.

Lamoureux, C. G. and Lastrapes, W. D. (1990) Persistence in variance, structural change and the GARCH model, Journal of Business and Economic Statistics 8, 225-234.

Lucas, R. E. (1972) Expectations and the neutrality of money, Journal of Economic Theory 4, 103-124.

Martin, P. and Rogers, C.A. (1997) Stabilization policy, learning by doing, and economic growth, Oxford Economic Papers 49, 152-166.

Martin, P. and Rogers, C.A. (2000) Long-term growth and short-term economic instability, European Economic Review 44, 359-381.

McConnell, M. M. and Perez-Quiros, G. (2000) Output fluctuations in the United States: What has changed since the early 1980’s? American Economic Review 90, 1464-1476.

Mikosch, T. and Stărică, C. (2004) Non-stationarities in financial time series, the long-range dependence, and the IGARCH effects, Review of Economics and Statistics 86, 378-390.

Mills, T. C. and Wang, P. (2003) Have output growth rates stabilized? Evidence from the G-7 economies, Scottish Journal of Political Economy 50, 232-246.

Pagan, A. and Ullah, A. (1988) The econometric analysis of models with risk terms, Journal of Applied Econometrics 3, 87-105.

Phelps, E. S. (1968) Money wage dynamics and labor market equilibrium, Journal of Political Economy 76, 678-711.

Stock, J. H. and Watson, M. W. (2003) Has the business cycle changed? Evidence and explanations, Monetary Policy and Uncertainty: Adapting to a Changing Economy, proceedings of symposium sponsored by Federal Reserve Bank of Kansas City, Jackson Hole, Wyo., 9-56.

Summers, P. M. (2005) What caused the Great Moderation? Some cross-country evidence, Economic Review (Third Quarter), Federal Reserve Bank of Kansas City, 5-32.

Taylor, J. (1979) Estimation and control of a macroeconomic model with rational expectations, Econometrica 47, 1267-1286.

Tolvi, J. (2001) Outliers in eleven Finnish macroeconomic time series, Finnish Economic Papers $14,14-32$. 
Tsay, R. S. (1988) Outliers, level shifts and variance changes in time series, Journal of Forecasting 7, 1-20.

Ungar, M. and Zilberfarb, B. (1993) Inflation and its unpredictability - theory and empirical evidence, Journal of Money, Credit, and Banking 25, 709-720.

van Dijk, D., Franses, P. H., and Lucas, A. (1999) Testing for ARCH in the presence of additive outliers, Journal of Applied Econometrics 14, 539-562.

Young, A. T., and Du, S., (2007). Did leaving the Gold Standard tame the business cycle? Evidence from NBER reference dates and real GNP. Available at SSRN: http://ssrn.com/abstract=985152. 
Table 1: $\quad$ Descriptive Statistics for Quarterly Real GNP, 1875:Q1-2008:Q2

Panel A. Quarterly Real GNP Growth

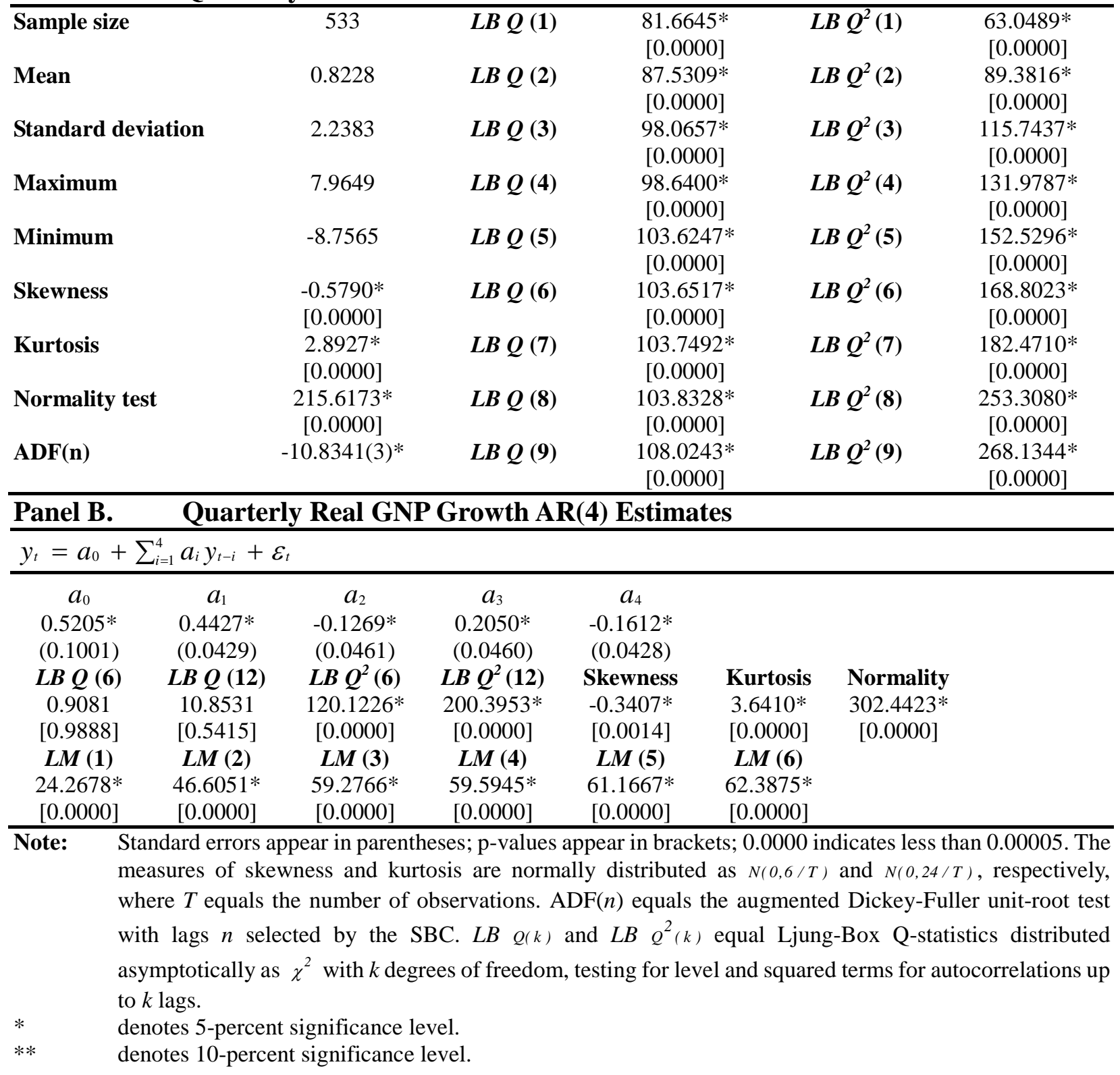


Table 2: $\quad$ Descriptive Statistics for Quarterly Real GNP, 1875:Q1-2008:Q2 (Critical Value by $k=3$ )

Panel A. Quarterly Real GNP Growth

\begin{tabular}{|c|c|c|c|c|c|}
\hline Sample size & 533 & $L B Q(1)$ & $\begin{array}{l}88.3310^{*} \\
{[0.0000]}\end{array}$ & $L B Q^{2}(1)$ & $\begin{array}{l}73.3568^{*} \\
{[0.0000]}\end{array}$ \\
\hline Mean & 0.9163 & $L B Q(2)$ & $\begin{array}{c}103.3467 * \\
{[0.0000]}\end{array}$ & $L B Q^{2}(2)$ & $\begin{array}{c}108.7103 * \\
{[0.0000]}\end{array}$ \\
\hline Standard deviation & 1.6246 & $L B Q(3)$ & $\begin{array}{c}117.0545^{*} \\
{[0.0000]}\end{array}$ & $L B Q^{2}(3)$ & $\begin{array}{c}166.0098 * \\
{[0.0000]}\end{array}$ \\
\hline Maximum & 5.7512 & $L B Q(4)$ & $\begin{array}{c}117.3284 * \\
{[0.0000]}\end{array}$ & $L B Q^{2}(4)$ & $\begin{array}{c}214.9633^{*} \\
{[0.0000]}\end{array}$ \\
\hline Minimum & -4.2890 & $L B Q(5)$ & $\begin{array}{c}122.1291^{*} \\
{[0.0000]}\end{array}$ & $L B Q^{2}(5)$ & $\begin{array}{c}232.7550 * \\
{[0.0000]}\end{array}$ \\
\hline Skewness & $\begin{array}{c}0.0383 \\
{[0.7188]}\end{array}$ & $L B Q(6)$ & $\begin{array}{c}122.2763 * \\
{[0.0000]}\end{array}$ & $L B Q^{2}(6)$ & $\begin{array}{c}259.6555^{*} \\
{[0.0000]}\end{array}$ \\
\hline Kurtosis & $\begin{array}{l}0.5496^{*} \\
{[0.0100]}\end{array}$ & $L B Q(7)$ & $\begin{array}{c}122.3000 * \\
{[0.0000]}\end{array}$ & $L B Q^{2}(7)$ & $\begin{array}{c}270.8399 * \\
{[0.0000]}\end{array}$ \\
\hline Normality test & $\begin{array}{c}6.8386 * \\
{[0.0327]}\end{array}$ & $L B Q(8)$ & $\begin{array}{c}122.3246 * \\
{[0.0000]}\end{array}$ & $L B Q^{2}(8)$ & $\begin{array}{c}305.5707 * \\
{[0.0000]}\end{array}$ \\
\hline ADF(n) & $-14.9648(0)^{*}$ & $L B Q(9)$ & $\begin{array}{c}126.5871^{*} \\
{[0.0000]}\end{array}$ & $L B Q^{2}(9)$ & $\begin{array}{c}331.8204 * \\
{[0.0000]}\end{array}$ \\
\hline
\end{tabular}

Panel B. Quarterly Real GNP Growth AR(4) Estimates

\begin{tabular}{|c|c|c|c|c|c|c|}
\hline \multicolumn{7}{|c|}{$y_{t}=a_{0}+\sum_{i=1}^{4} a_{i} y_{t-i}+\varepsilon_{t}$} \\
\hline$a_{0}$ & $a_{1}$ & $a_{2}$ & $a_{3}$ & $a_{4}$ & & \\
\hline $0.5185 *$ & $0.4143 *$ & -0.0330 & $0.1405 *$ & $-0.0948 *$ & & \\
\hline$(0.0827)$ & $(0.0430)$ & $(0.0462)$ & $(0.0460)$ & $(0.0429)$ & & \\
\hline$L B Q(6)$ & $L B Q(12)$ & $L B Q^{2}(\mathbf{6})$ & $L B Q^{2}(12)$ & Skewness & Kurtosis & Normality \\
\hline 9.9923 & 15.9125 & $291.1085 *$ & $505.8934 *$ & 0.0757 & 0.2343 & 1.7164 \\
\hline [0.1249] & [0.1952] & {$[0.0000]$} & {$[0.0000]$} & [0.4781] & {$[0.2744]$} & [0.4239] \\
\hline$L M(1)$ & $L M(2)$ & $L M(3)$ & $L M(4)$ & $L M(5)$ & $L M(6)$ & \\
\hline $38.8847 *$ & $77.2316^{*}$ & $94.7072 *$ & $110.8972 *$ & $115.6021 *$ & $117.2286^{*}$ & \\
\hline$[0.0000]$ & {$[0.0000]$} & {$[0.0000]$} & {$[0.0000]$} & {$[0.0000]$} & {$[0.0000]$} & \\
\hline
\end{tabular}

\footnotetext{
Note: $\quad$ See Table 1.

* denotes 5-percent significance level.

** denotes 10-percent significance level.
} 
Table 3: Bai and Perron (1998) Structural Break Test and Break Date

\begin{tabular}{|c|c|c|c|c|}
\hline & \multicolumn{2}{|c|}{ Pure Structural Break } & \multicolumn{2}{|c|}{ Partial Structural Break } \\
\hline & Mean & Variance & Mean & Variance \\
\hline \multirow[t]{2}{*}{$\overline{S u p ~} F(1 \mid 0)$} & 14.0145 & $73.4623 *$ & 2.0179 & $76.7664 *$ \\
\hline & [18.2300] & [8.5800] & {$[8.5800]$} & [8.5800] \\
\hline \multirow[t]{2}{*}{$\operatorname{Sup} F(2 \mid 0)$} & 15.5203 & $51.3302 *$ & 1.7890 & $54.9842 *$ \\
\hline & [15.6200] & [7.2200] & [7.2200] & [7.2200] \\
\hline \multirow{2}{*}{$\operatorname{Sup} F(3 \mid 0)$} & $14.0973^{*}$ & $81.1428 *$ & 1.7463 & $62.9688 *$ \\
\hline & [13.9300] & {$[5.9600]$} & [5.9600] & [5.9600] \\
\hline \multirow{2}{*}{$\operatorname{Sup} F(4 \mid 0)$} & $13.2340 *$ & $60.9688 *$ & 1.6418 & 49.6966* \\
\hline & [12.3800] & [4.9900] & [4.9900] & [4.9900] \\
\hline \multirow{2}{*}{ Sup $F(5 \mid 0)$} & $13.5140 *$ & 48.2529* & 0.9565 & $39.8136 *$ \\
\hline & [10.5200] & [3.9100] & [3.9100] & [3.9100] \\
\hline \multirow[t]{2}{*}{$U D_{\operatorname{Max}}$} & 15.5203 & $81.1428 *$ & 2.0179 & $76.7664 *$ \\
\hline & [18.4200] & {$[8.8800]$} & [8.8800] & [8.8800] \\
\hline \multirow{2}{*}{$W D_{M a x}$} & $23.4183 *$ & $116.8129 *$ & 2.8229 & 90.6498* \\
\hline & [19.9600] & [9.9100] & [9.9100] & [9.9100] \\
\hline \multirow{2}{*}{ Sup $F(2 \mid 1)$} & 16.6217 & $43.7844 *$ & 1.5136 & $32.3612 *$ \\
\hline & [19.9100] & [10.1300] & {$[10.1300]$} & [10.1300] \\
\hline \multirow{2}{*}{$\operatorname{Sup} F(3 \mid 2)$} & 12.1317 & $43.7844 *$ & 1.6373 & $35.6135^{*}$ \\
\hline & [20.9900] & [11.1400] & {$[11.1400]$} & [11.1400] \\
\hline \multirow[t]{2}{*}{ Sup $F(4 \mid 3)$} & 5.5802 & 2.8801 & 1.4164 & 0.0713 \\
\hline & {$[21.7100]$} & [11.8300] & {$[11.8300]$} & [11.8300] \\
\hline \multirow{2}{*}{ Sup $F(5 \mid 4)$} & - & 0.2401 & - & 0.0713 \\
\hline & & {$[12.2500]$} & & {$[12.2500]$} \\
\hline \multirow[t]{3}{*}{$\overline{\text { Break date }}$} & 1936:2 & $1916: 4$ & NA & $1916: 4$ \\
\hline & & 1950:3 & & 1950:3 \\
\hline & & 1983:4 & & 1982:3 \\
\hline \multirow[t]{3}{*}{ 95\% Confidence Interval } & 1912:3-1962:4 & $1905: 4-1922: 4$ & NA & $1906: 1-1920: 4$ \\
\hline & & 1948:4-1956:1 & & 1949:2-1956:1 \\
\hline & & 1982:2-1990:3 & & 1979:3-1990:1 \\
\hline
\end{tabular}

Note: $\quad$ Critical values for the 5-percent significance level appear in parentheses. In the detection process, we require $15 \%$ of the full sample as the minimal length of any partition. Thus, - indicates that no more place exists to insert an additional break given the minimal length requirement.

* denotes 5-percent significance level. 


\section{Table 4. Cross-Sample Structural Stability Test}

Panel A. Pure Structural Break Specification

\begin{tabular}{lccccc}
\hline & Sub-sample & $\begin{array}{c}\text { Sub-sample 1 } \\
(1876: 1-1936: 2)\end{array}$ & $\begin{array}{c}\text { Sub-sample 2 } \\
(1936: 2-2008: 2)\end{array}$ & & \\
\hline Mean & Sub-sample 1 & 0.9124 & & & \\
& $(1876: 1-1936: 2)$ & & & & \\
& Sub-sample 2 & -0.0491 & 0.9196 & & \\
\hline & $(1936: 2-2008: 2)$ & {$[0.9607]$} & & & \\
\hline Standard & Sub-sample & Sub-sample 1 & Sub-sample 2 & Sub-sample 3 & Sub-sample 4 \\
Deviation & Sub-sample 1 & $1.576: 1-1916: 4)$ & $(1917: 1-1950: 3)$ & $(1950: 4-1983: 4)$ & $(1984: 1-2008: 2)$ \\
& $(1876: 1-1916: 4)$ & & & & \\
& Sub-sample 2 & $0.4304^{*}$ & 2.4199 & & \\
& $(1917: 1-1950: 3)$ & {$[0.0000]$} & & 1.1303 & \\
& Sub-sample 3 & $1.9728 *$ & $4.5831^{*}$ & & \\
& $(1950: 4-1983: 4)$ & {$[0.0000]$} & {$[0.0000]$} & & \\
& Sub-sample 4 & $9.2063^{*}$ & $21.3875^{*}$ & $4.6665^{*}$ & 0.5232 \\
& $(1984: 1-2008: 2)$ & {$[0.0000]$} & {$[0.0000]$} & {$[0.0000]$} & \\
\hline
\end{tabular}

Panel B. Partial Structural Break Specification

\begin{tabular}{|c|c|c|c|c|c|}
\hline & Sub-sample & $\begin{array}{c}\text { Sub-sample 1 } \\
(1876: 1-1916: 4)\end{array}$ & $\begin{array}{c}\text { Sub-sample } 2 \\
(1917: 1-1950: 3)\end{array}$ & $\begin{array}{c}\text { Sub-sample } 3 \\
(1950: 4-1982: 3)\end{array}$ & $\begin{array}{c}\text { Sub-sample } 4 \\
(1982: 4-2008: 2)\end{array}$ \\
\hline \multirow[t]{6}{*}{$\begin{array}{l}\text { Standard } \\
\text { Deviation }\end{array}$} & $\begin{array}{c}\text { Sub-sample } 1 \\
(1876: 1-1916: 4)\end{array}$ & 1.5877 & & & \\
\hline & Sub-sample 2 & $0.4304 *$ & 2.4199 & & \\
\hline & (1917:1-1950:3) & {$[0.0000]$} & & & \\
\hline & Sub-sample 3 & 1.9624* & 4.5591* & 1.1333 & \\
\hline & $(1950: 4-1982: 3)$ & [0.0000] & {$[0.0000]$} & & \\
\hline & $\begin{array}{c}\text { Sub-sample } 4 \\
(1982: 4-2008: 2) \\
\end{array}$ & $\begin{array}{l}\text { 7.8999* } \\
{[0.0000]}\end{array}$ & $\begin{array}{l}18.3526 * \\
{[0.0000]}\end{array}$ & $\begin{array}{l}4.0254^{*} \\
{[0.0000]}\end{array}$ & 0.5648 \\
\hline Note: & $\begin{array}{l}\text { P-values appear in bra } \\
\text { for structural change } \\
\text { unconditional varianc } \\
F\left(d f_{i}, d f_{j}\right) \text {, where } d f \mathrm{de}\end{array}$ & $\begin{array}{l}\text { ets; } 0.0000 \text { indicat } \\
\text { the uncondition } \\
\text { ratio test betwee } \\
\text { tes the degrees of }\end{array}$ & $\begin{array}{l}\text { ess than } 0.00005 \text {. } \\
\text { mean between } t \\
\text { e samples } i \text { and } \\
\text { dom. }\end{array}$ & $\begin{array}{l}\text {-statistic under u } \\
\text { different regime } \\
\text { and is asympto }\end{array}$ & $\begin{array}{l}\text { qual variances tests } \\
F \text { test equals the } \\
\text { ally distributed as }\end{array}$ \\
\hline * & $\begin{array}{l}\text { denotes } 5 \text {-percent sig } \\
\text { denotes } 10 \text {-percent si }\end{array}$ & $\begin{array}{l}\text { ance level. } \\
\text { cance level. }\end{array}$ & & & \\
\hline
\end{tabular}




\begin{tabular}{|c|c|c|c|c|c|c|c|}
\hline & (1) & $(2)$ & (3) & (4) & (5) & (6) & (7) \\
\hline$a_{0}$ & $\begin{array}{l}0.4892 * \\
(0.0735)\end{array}$ & $\begin{array}{l}0.5031^{*} \\
(0.0702)\end{array}$ & $\begin{array}{l}0.5663 * \\
(0.1317)\end{array}$ & $\begin{array}{l}0.6164^{*} \\
(0.1299)\end{array}$ & $\begin{array}{l}0.5842 * \\
(0.1306)\end{array}$ & $\begin{array}{c}0.2497 \\
(0.2206)\end{array}$ & $\begin{array}{c}0.1891 \\
(0.2246)\end{array}$ \\
\hline$a_{1}$ & $\begin{array}{l}0.3941 * \\
(0.0504)\end{array}$ & $\begin{array}{l}0.3482 * \\
(0.0461)\end{array}$ & $\begin{array}{l}0.4204 * \\
(0.0645)\end{array}$ & $\begin{array}{l}0.4142 * \\
(0.0633)\end{array}$ & $\begin{array}{l}0.4135^{*} \\
(0.0636)\end{array}$ & $\begin{array}{l}0.4418^{*} \\
(0.0634)\end{array}$ & $\begin{array}{l}0.4298 * \\
(0.0637)\end{array}$ \\
\hline$a_{2}$ & $\begin{array}{c}0.0549 \\
(0.0569)\end{array}$ & $\begin{array}{l}0.0921 * \\
(0.0471)\end{array}$ & $\begin{array}{l}-0.0331 \\
(0.0654)\end{array}$ & $\begin{array}{c}-0.0411 \\
(0.0646)\end{array}$ & $\begin{array}{c}-0.0374 \\
(0.0656)\end{array}$ & $\begin{array}{c}-0.0574 \\
(0.0637)\end{array}$ & $\begin{array}{c}-0.0453 \\
(0.0642)\end{array}$ \\
\hline$a_{3}$ & $\begin{array}{l}-0.0012 \\
(0.0491)\end{array}$ & $\begin{array}{c}0.0034 \\
(0.0470)\end{array}$ & $\begin{array}{c}0.1118 * * \\
(0.0646)\end{array}$ & $\begin{array}{c}0.1243 * * \\
(0.0698)\end{array}$ & $\begin{array}{c}0.1314^{* *} \\
(0.0697)\end{array}$ & $\begin{array}{c}0.1172^{* *} \\
(0.0690)\end{array}$ & $\begin{array}{c}0.1194 * * \\
(0.0690)\end{array}$ \\
\hline$a_{4}$ & $\begin{array}{c}-0.0780 \\
(0.0479)\end{array}$ & $\begin{array}{l}-0.0664 \\
(0.0438)\end{array}$ & $\begin{array}{c}-0.1959 * \\
(0.0661)\end{array}$ & $\begin{array}{c}-0.1940^{*} \\
(0.0690)\end{array}$ & $\begin{array}{l}-0.1904^{*} \\
(0.0688)\end{array}$ & $\begin{array}{c}-0.1995 * \\
(0.0671)\end{array}$ & $\begin{array}{l}-0.1647 * \\
(0.0679)\end{array}$ \\
\hline$b_{0}$ & & & $\begin{array}{l}-0.1207 \\
(0.1589)\end{array}$ & $\begin{array}{l}-0.1504 \\
(0.1507)\end{array}$ & $\begin{array}{l}-0.1423 \\
(0.1519)\end{array}$ & $\begin{array}{l}-0.0053 \\
(0.1936)\end{array}$ & $\begin{array}{c}0.0826 \\
(0.1888)\end{array}$ \\
\hline$b_{1}$ & & & $\begin{array}{l}-0.1117 \\
(0.0909)\end{array}$ & $\begin{array}{l}-0.0865 \\
(0.0880)\end{array}$ & $\begin{array}{l}-0.0947 \\
(0.0904)\end{array}$ & $\begin{array}{l}-0.0803 \\
(0.0887)\end{array}$ & $\begin{array}{l}-0.1328 \\
(0.0877)\end{array}$ \\
\hline$b_{2}$ & & & $\begin{array}{l}0.2058^{*} \\
(0.0914)\end{array}$ & $\begin{array}{l}0.1930^{*} \\
(0.0913)\end{array}$ & $\begin{array}{c}0.20448^{*} \\
(0.0911)\end{array}$ & $\begin{array}{l}0.2187^{*} \\
(0.0901)\end{array}$ & $\begin{array}{l}0.2146^{*} \\
(0.0884)\end{array}$ \\
\hline$b_{3}$ & & & $\begin{array}{l}-0.1739 * \\
(0.0909)\end{array}$ & $\begin{array}{c}-0.2073^{*} \\
(0.0916)\end{array}$ & $\begin{array}{c}-0.2173^{*} \\
(0.0923)\end{array}$ & $\begin{array}{c}-0.2076^{*} \\
(0.0905)\end{array}$ & $\begin{array}{l}-0.1770^{*} \\
(0.0913)\end{array}$ \\
\hline$b_{4}$ & & & $\begin{array}{l}0.2291^{*} \\
(0.0884)\end{array}$ & $\begin{array}{l}0.2258^{*} \\
(0.0900)\end{array}$ & $\begin{array}{l}0.2351^{*} \\
(0.0905)\end{array}$ & $\begin{array}{l}0.2484^{*} \\
(0.0896)\end{array}$ & $\begin{array}{l}0.2081^{*} \\
(0.0890)\end{array}$ \\
\hline$\lambda$ & & & & & & $\begin{array}{l}0.2630 * \\
(0.1206)\end{array}$ & $\begin{array}{l}0.2344 * \\
(0.1150)\end{array}$ \\
\hline$\alpha_{0}$ & $\begin{array}{c}0.0039 \\
(0.0069)\end{array}$ & $\begin{array}{c}0.0082 \\
(0.0067)\end{array}$ & $\begin{array}{c}0.0085 \\
(0.0063)\end{array}$ & $\begin{array}{l}0.5933 * \\
(0.2261)\end{array}$ & $\begin{array}{l}0.5937 * \\
(0.1680)\end{array}$ & $\begin{array}{l}0.3235^{*} \\
(0.1175)\end{array}$ & $\begin{array}{l}0.6130 * \\
(0.1582)\end{array}$ \\
\hline$\alpha_{1}$ & $\begin{array}{l}0.1219^{*} \\
(0.0279)\end{array}$ & $\begin{array}{c}0.1192 * \\
(0.0225)\end{array}$ & $\begin{array}{l}0.1264^{*} \\
(0.0225)\end{array}$ & $\begin{array}{l}0.0967^{*} \\
(0.0420)\end{array}$ & $\begin{array}{c}0.0825^{* *} \\
(0.0493)\end{array}$ & $\begin{array}{l}0.0900^{*} \\
(0.0313)\end{array}$ & $\begin{array}{c}0.1158^{*} \\
(0.0422)\end{array}$ \\
\hline$\beta_{1}$ & $\begin{array}{l}0.8889 * \\
(0.0206)\end{array}$ & $\begin{array}{l}0.8798 * \\
(0.0220)\end{array}$ & $\begin{array}{l}0.8732 * \\
(0.0213)\end{array}$ & $\begin{array}{l}0.6148 * \\
(0.1290)\end{array}$ & $\begin{array}{l}0.6787 * \\
(0.1157)\end{array}$ & $\begin{array}{l}0.7439 * \\
(0.0706)\end{array}$ & $\begin{array}{l}0.6497 * \\
(0.0890)\end{array}$ \\
\hline$\gamma_{1}$ & & & & $\begin{array}{l}0.6312^{*} \\
(0.2934)\end{array}$ & $\begin{array}{l}0.4318^{*} \\
(0.1925)\end{array}$ & $\begin{array}{l}0.2755^{*} \\
(0.1420)\end{array}$ & $\begin{array}{l}0.3807^{*} \\
(0.1812)\end{array}$ \\
\hline$\gamma_{2}$ & & & & $\begin{array}{l}-0.8755^{*} \\
(0.3436)\end{array}$ & $\begin{array}{l}-0.6697^{*} \\
(0.2408)\end{array}$ & $\begin{array}{l}-0.3995 * \\
(0.1585)\end{array}$ & $\begin{array}{l}-0.6143^{*} \\
(0.2107)\end{array}$ \\
\hline$\gamma_{3}$ & & & & $\begin{array}{l}-0.2816^{*} \\
(0.1326)\end{array}$ & $\begin{array}{c}-0.2313 * \\
(0.0867)\end{array}$ & $\begin{array}{l}-0.1710^{*} \\
(0.0755)\end{array}$ & $\begin{array}{l}-0.2503^{*} \\
(0.0844)\end{array}$ \\
\hline$\delta$ & & & & & $\begin{array}{l}-0.0890^{*} \\
(0.0308)\end{array}$ & & $\begin{array}{l}-0.0960^{*} \\
(0.0243)\end{array}$ \\
\hline LR & $\begin{array}{c}0.5551 \\
{[0.4566]}\end{array}$ & $\begin{array}{c}0.0092 \\
{[0.9233]}\end{array}$ & $\begin{array}{c}0.0009 \\
{[0.9750]}\end{array}$ & $\begin{array}{l}7.3333 * \\
{[0.0070]}\end{array}$ & $\begin{array}{l}8.7611^{*} \\
{[0.0032]}\end{array}$ & $\begin{array}{l}8.9238 * \\
{[0.0029]}\end{array}$ & $\begin{array}{l}11.5363^{*} \\
{[0.0007]}\end{array}$ \\
\hline Function value & -986.0413 & -867.6055 & -861.5766 & -846.5214 & -846.3065 & -848.2876 & -844.8263 \\
\hline$\overline{L B Q(6)}$ & $\begin{array}{c}4.2322 \\
{[0.6452]}\end{array}$ & $\begin{array}{c}8.0472 \\
{[0.2346]}\end{array}$ & $\begin{array}{c}4.8343 \\
{[0.5652]}\end{array}$ & $\begin{array}{c}5.5430 \\
{[0.4762]}\end{array}$ & $\begin{array}{c}5.9473 \\
{[0.4291]}\end{array}$ & $\begin{array}{c}6.4416 \\
{[0.3755]}\end{array}$ & $\begin{array}{c}5.3606 \\
{[0.4984]}\end{array}$ \\
\hline$L B Q(12)$ & $\begin{array}{c}9.1435 \\
{[0.6906]}\end{array}$ & $\begin{array}{l}11.2388 \\
{[0.5085]}\end{array}$ & $\begin{array}{c}7.4793 \\
{[0.8243]}\end{array}$ & $\begin{array}{l}10.4005 \\
{[0.5808]}\end{array}$ & $\begin{array}{c}10.8923 \\
{[0.5381]}\end{array}$ & $\begin{array}{c}11.2514 \\
{[0.5075]}\end{array}$ & $\begin{array}{l}10.4588 \\
{[0.5757]}\end{array}$ \\
\hline$L B Q^{2}(6)$ & $\begin{array}{c}5.2126 \\
{[0.5168]}\end{array}$ & $\begin{array}{c}1.7684 \\
{[0.9397]}\end{array}$ & $\begin{array}{c}2.1661 \\
{[0.9038]}\end{array}$ & $\begin{array}{c}6.0501 \\
{[0.4176]}\end{array}$ & $\begin{array}{c}5.6035 \\
{[0.4690]}\end{array}$ & $\begin{array}{c}4.9441 \\
{[0.5509]}\end{array}$ & $\begin{array}{c}5.9228 \\
{[0.4318]}\end{array}$ \\
\hline$L B Q^{2}(12)$ & $\begin{array}{l}26.5926^{*} \\
{[0.0088]}\end{array}$ & $\begin{array}{c}5.6750 \\
{[0.9315]}\end{array}$ & $\begin{array}{c}5.1228 \\
{[0.9537]}\end{array}$ & $\begin{array}{l}13.6767 \\
{[0.3218]}\end{array}$ & $\begin{array}{l}11.0833 \\
{[0.5217]}\end{array}$ & $\begin{array}{c}8.0936 \\
{[0.7777]}\end{array}$ & $\begin{array}{c}9.8225 \\
{[0.6315]}\end{array}$ \\
\hline Skewness & $\begin{array}{l}-0.3502 * \\
{[0.0010]}\end{array}$ & $\begin{array}{c}-0.1422 \\
{[0.1829]}\end{array}$ & $\begin{array}{c}-0.1263 \\
{[0.2366]}\end{array}$ & $\begin{array}{c}-0.0621 \\
{[0.5608]}\end{array}$ & $\begin{array}{c}-0.0529 \\
{[0.6199]}\end{array}$ & $\begin{array}{c}-0.0391 \\
{[0.7137]}\end{array}$ & $\begin{array}{c}-0.0304 \\
{[0.7753]}\end{array}$ \\
\hline Kurtosis & $\begin{array}{l}2.0828^{*} \\
{[0.0000]}\end{array}$ & $\begin{array}{c}0.0651 \\
{[0.7611]}\end{array}$ & $\begin{array}{c}0.1234 \\
{[0.5649]}\end{array}$ & $\begin{array}{c}-0.3234 \\
{[0.1314]}\end{array}$ & $\begin{array}{c}-0.3023 \\
{[0.1585]}\end{array}$ & $\begin{array}{c}-0.3657 \\
{[0.1011]}\end{array}$ & $\begin{array}{c}-0.3348 \\
{[0.1183]}\end{array}$ \\
\hline Normality & $\begin{array}{c}106.4392 * \\
{[0.0000]}\end{array}$ & $\begin{array}{c}1.8770 \\
{[0.3911]}\end{array}$ & $\begin{array}{c}1.7441 \\
{[0.4180]}\end{array}$ & $\begin{array}{c}2.6456 \\
{[0.2663]}\end{array}$ & $\begin{array}{c}2.2622 \\
{[0.3226]}\end{array}$ & $\begin{array}{c}2.9756 \\
{[0.2258]}\end{array}$ & $\begin{array}{c}2.5530 \\
{[0.2789]}\end{array}$ \\
\hline
\end{tabular}

Note: $\quad$ Column (1) without outlier corrected, column (2)-(7) with outlier corrected. Standard errors appear in parentheses; p-values appear in brackets; $L B Q(k)$ and $L B Q^{2}(k)$ equal Ljung-Box Q-statistics, testing for standardized residuals and squared standardized residuals for autocorrelations up to $k$ lags, where the degrees of freedom are reduced by the number of estimated coefficients in the mean equation. LR equals the likelihood ratio statistic, following a $\chi^{2}$ distribution with one degree of freedom that tests for $\alpha_{1}+\beta_{1}=1$.

* denotes 5-percent significance level.

** denotes 10 -percent significance level. 
Table 6:EGARCH Model Estimation

\begin{tabular}{|c|c|c|c|c|c|c|c|}
\hline & (1) & $(2)$ & (3) & (4) & (5) & (6) & (7) \\
\hline$a_{0}$ & $\begin{array}{c}0.4474 * \\
(0.0749)\end{array}$ & $\begin{array}{l}0.4774 * \\
(0.0697)\end{array}$ & $\begin{array}{l}0.6217 * \\
(0.1155)\end{array}$ & $\begin{array}{l}0.5771^{*} \\
(0.1284)\end{array}$ & $\begin{array}{l}0.5885^{*} \\
(0.1237)\end{array}$ & $\begin{array}{c}0.2919 \\
(0.2335)\end{array}$ & $\begin{array}{c}0.3057 \\
(0.2236)\end{array}$ \\
\hline$a_{1}$ & $\begin{array}{l}0.4323^{*} \\
(0.0543)\end{array}$ & $\begin{array}{l}0.3499 * \\
(0.0455)\end{array}$ & $\begin{array}{l}0.4476^{*} \\
(0.0626)\end{array}$ & $\begin{array}{l}0.4245^{*} \\
(0.0622)\end{array}$ & $\begin{array}{l}0.4493^{*} \\
(0.0609)\end{array}$ & $\begin{array}{l}0.4377^{*} \\
(0.0635)\end{array}$ & $\begin{array}{l}0.4582^{*} \\
(0.0612)\end{array}$ \\
\hline$a_{2}$ & $\begin{array}{c}0.0402 \\
(0.0544)\end{array}$ & $\begin{array}{l}0.0949 * \\
(0.0468)\end{array}$ & $\begin{array}{c}-0.0489 \\
(0.0642)\end{array}$ & $\begin{array}{l}-0.0315 \\
(0.0657)\end{array}$ & $\begin{array}{l}-0.0507 \\
(0.0645)\end{array}$ & $\begin{array}{l}-0.0373 \\
(0.0652)\end{array}$ & $\begin{array}{c}-0.0515 \\
(0.0643)\end{array}$ \\
\hline$a_{3}$ & $\begin{array}{c}-0.0042 \\
(0.0471)\end{array}$ & $\begin{array}{c}-0.0021 \\
(0.0473)\end{array}$ & $\begin{array}{c}0.0912 \\
(0.0665)\end{array}$ & $\begin{array}{c}0.1125 \\
(0.0714)\end{array}$ & $\begin{array}{c}0.1222^{* *} \\
(0.0683)\end{array}$ & $\begin{array}{c}0.1189 * * \\
(0.0650)\end{array}$ & $\begin{array}{c}0.1236 * * \\
(0.0694)\end{array}$ \\
\hline$a_{4}$ & $\begin{array}{l}-0.0699 \\
(0.0456)\end{array}$ & $\begin{array}{l}-0.0535 \\
(0.0437)\end{array}$ & $\begin{array}{c}-0.1927^{*} \\
(0.0632)\end{array}$ & $\begin{array}{l}-0.1937 * \\
(0.0667)\end{array}$ & $\begin{array}{c}-0.2198^{*} \\
(0.0616)\end{array}$ & $\begin{array}{c}-0.1964 * \\
(0.0650)\end{array}$ & $\begin{array}{c}-0.2282^{*} \\
(0.0607)\end{array}$ \\
\hline$b_{0}$ & & & $\begin{array}{l}-0.2784 * \\
(0.1373)\end{array}$ & $\begin{array}{c}-0.1398 \\
(0.1491)\end{array}$ & $\begin{array}{c}-0.1393 \\
(0.1431)\end{array}$ & $\begin{array}{c}0.0292 \\
(0.1891)\end{array}$ & $\begin{array}{c}0.0226 \\
(0.1766)\end{array}$ \\
\hline$b_{1}$ & & & $\begin{array}{l}-0.1288 \\
(0.0887)\end{array}$ & $\begin{array}{l}-0.1164 \\
(0.0860)\end{array}$ & $\begin{array}{c}-0.1569 * * \\
(0.0861)\end{array}$ & $\begin{array}{l}-0.1323 \\
(0.0868)\end{array}$ & $\begin{array}{c}-0.1626^{* *} \\
(0.0857)\end{array}$ \\
\hline$b_{2}$ & & & $\begin{array}{l}0.2432 * \\
(0.0892)\end{array}$ & $\begin{array}{l}0.2060^{*} \\
(0.0910)\end{array}$ & $\begin{array}{l}0.2280^{*} \\
(0.0897)\end{array}$ & $\begin{array}{l}0.2114^{*} \\
(0.0905)\end{array}$ & $\begin{array}{l}0.2275^{*} \\
(0.0895)\end{array}$ \\
\hline$b_{3}$ & & & $\begin{array}{c}-0.1538 * * \\
(0.0888)\end{array}$ & $\begin{array}{c}-0.1958^{*} \\
(0.0927)\end{array}$ & $\begin{array}{l}-0.2060^{*} \\
(0.0902)\end{array}$ & $\begin{array}{c}-0.2050^{*} \\
(0.0916)\end{array}$ & $\begin{array}{l}-0.2119 * \\
(0.0907)\end{array}$ \\
\hline$b_{4}$ & & & $\begin{array}{l}0.2560 * \\
(0.0863)\end{array}$ & $\begin{array}{l}0.2439 * \\
(0.0877)\end{array}$ & $\begin{array}{l}0.2665^{*} \\
(0.0836)\end{array}$ & $\begin{array}{l}0.2503^{*} \\
(0.0865)\end{array}$ & $\begin{array}{l}0.2773^{*} \\
(0.0830)\end{array}$ \\
\hline$\lambda$ & & & & & & $\begin{array}{c}0.1848 \\
(0.1248)\end{array}$ & $\begin{array}{c}0.1882 \\
(0.1251)\end{array}$ \\
\hline$\alpha_{0}$ & $\begin{array}{c}-0.1967 * \\
(0.0312)\end{array}$ & $\begin{array}{c}-0.1679 * \\
(0.0313)\end{array}$ & $\begin{array}{c}-0.1475^{*} \\
(0.0301)\end{array}$ & $\begin{array}{c}0.0163 \\
(0.0635)\end{array}$ & $\begin{array}{c}-0.0256 \\
(0.0685)\end{array}$ & $\begin{array}{c}0.0119 \\
(0.0600)\end{array}$ & $\begin{array}{c}-0.0196 \\
(0.0660)\end{array}$ \\
\hline$\alpha_{1}$ & $\begin{array}{l}0.2714 * \\
(0.0474)\end{array}$ & $\begin{array}{l}0.2145^{*} \\
(0.0405)\end{array}$ & $\begin{array}{l}0.1873 * \\
(0.0384)\end{array}$ & $\begin{array}{l}0.1471^{*} \\
(0.0668)\end{array}$ & $\begin{array}{c}0.1306^{* *} \\
(0.0715)\end{array}$ & $\begin{array}{l}0.1489 * \\
(0.0623)\end{array}$ & $\begin{array}{l}0.1362 * \\
(0.0658)\end{array}$ \\
\hline$\alpha_{2}$ & $\begin{array}{c}-0.0663 * * \\
(0.0380)\end{array}$ & $\begin{array}{l}-0.0742^{*} \\
(0.0298)\end{array}$ & $\begin{array}{l}-0.1046 * \\
(0.0305)\end{array}$ & $\begin{array}{l}-0.1120^{*} \\
(0.0349)\end{array}$ & $\begin{array}{l}-0.2074 * \\
(0.0886)\end{array}$ & $\begin{array}{l}-0.1151^{*} \\
(0.0356)\end{array}$ & $\begin{array}{c}-0.2096 * \\
(0.0825)\end{array}$ \\
\hline$\beta_{1}$ & $\begin{array}{l}0.9910^{*} \\
(0.0075)\end{array}$ & $\begin{array}{l}0.9847^{*} \\
(0.0096)\end{array}$ & $\begin{array}{l}0.9858 * \\
(0.0091)\end{array}$ & $\begin{array}{l}0.8171^{*} \\
(0.0657)\end{array}$ & $\begin{array}{l}0.8321^{*} \\
(0.0683)\end{array}$ & $\begin{array}{l}0.8224^{*} \\
(0.0585)\end{array}$ & $\begin{array}{l}0.8191 * \\
(0.0617)\end{array}$ \\
\hline$\gamma_{1}$ & & & & $\begin{array}{l}0.1236^{*} \\
(0.0577)\end{array}$ & $\begin{array}{l}0.1125^{*} \\
(0.0558)\end{array}$ & $\begin{array}{l}0.1066^{*} \\
(0.0518)\end{array}$ & $\begin{array}{l}0.1008^{*} \\
(0.0527)\end{array}$ \\
\hline$\gamma_{2}$ & & & & $\begin{array}{l}-0.2350^{*} \\
(0.0864)\end{array}$ & $\begin{array}{l}-0.2114^{*} \\
(0.0933)\end{array}$ & $\begin{array}{l}-0.2263 * \\
(0.0770)\end{array}$ & $\begin{array}{l}-0.2254^{*} \\
(0.0840)\end{array}$ \\
\hline$\gamma_{3}$ & & & & $\begin{array}{c}-0.2918^{*} \\
(0.1017)\end{array}$ & $\begin{array}{c}-0.2559 * \\
(0.0890)\end{array}$ & $\begin{array}{l}-0.2647^{*} \\
(0.0899)\end{array}$ & $\begin{array}{c}-0.2448 * \\
(0.0828)\end{array}$ \\
\hline$\delta$ & & & & & $\begin{array}{c}0.0446 \\
(0.0341)\end{array}$ & & $\begin{array}{c}0.0446 \\
(0.0310)\end{array}$ \\
\hline LR & $\begin{array}{c}1.4035 \\
{[0.2367]}\end{array}$ & $\begin{array}{c}2.4839 \\
{[0.1156]}\end{array}$ & $\begin{array}{c}2.3977 \\
{[0.1221]}\end{array}$ & $\begin{array}{l}\text { 7.7313* } \\
{[0.0056]}\end{array}$ & $\begin{array}{l}6.0353^{*} \\
{[0.0144]}\end{array}$ & $\begin{array}{l}9.1857 * \\
{[0.0026]}\end{array}$ & $\begin{array}{l}8.5627 * \\
{[0.0036]}\end{array}$ \\
\hline Function value & -986.3654 & -865.5957 & -857.5925 & -843.9671 & -842.5171 & -842.7940 & -841.2278 \\
\hline$\overline{L B Q(6)}$ & $\begin{array}{c}4.6256 \\
{[0.5926]}\end{array}$ & $\begin{array}{c}8.2200 \\
{[0.2224]}\end{array}$ & $\begin{array}{c}5.5077 \\
{[0.4805]}\end{array}$ & $\begin{array}{c}5.5687 \\
{[0.4731]}\end{array}$ & $\begin{array}{c}4.8422 \\
{[0.5642]}\end{array}$ & $\begin{array}{c}5.4986 \\
{[0.4816]}\end{array}$ & $\begin{array}{c}4.8398 \\
{[0.5645]}\end{array}$ \\
\hline$L B Q(12)$ & $\begin{array}{l}10.1283 \\
{[0.6047]}\end{array}$ & $\begin{array}{l}11.4836 \\
{[0.4879]}\end{array}$ & $\begin{array}{c}8.2297 \\
{[0.7669]}\end{array}$ & $\begin{array}{l}10.5937 \\
{[0.5640]}\end{array}$ & $\begin{array}{c}9.7879 \\
{[0.6345]}\end{array}$ & $\begin{array}{l}10.6308 \\
{[0.5607]}\end{array}$ & $\begin{array}{c}9.8977 \\
{[0.6249]}\end{array}$ \\
\hline$L B Q^{2}(6)$ & $\begin{array}{c}5.4832 \\
{[0.4834]}\end{array}$ & $\begin{array}{c}2.3737 \\
{[0.8823]}\end{array}$ & $\begin{array}{c}1.9877 \\
{[0.9208]}\end{array}$ & $\begin{array}{c}4.6772 \\
{[0.5858]}\end{array}$ & $\begin{array}{c}3.8734 \\
{[0.6938]}\end{array}$ & $\begin{array}{c}4.3816 \\
{[0.6251]}\end{array}$ & $\begin{array}{c}3.6731 \\
{[0.7208]}\end{array}$ \\
\hline$L B Q^{2}(12)$ & $\begin{array}{l}34.1805^{*} \\
{[0.0006]}\end{array}$ & $\begin{array}{c}6.5298 \\
{[0.8870]}\end{array}$ & $\begin{array}{c}4.4710 \\
{[0.9733]}\end{array}$ & $\begin{array}{l}11.0131 \\
{[0.5277]}\end{array}$ & $\begin{array}{c}9.5219 \\
{[0.6578]}\end{array}$ & $\begin{array}{c}9.3488 \\
{[0.6728]}\end{array}$ & $\begin{array}{c}8.5080 \\
{[0.7442]}\end{array}$ \\
\hline Skewness & $\begin{array}{l}-0.4115^{*} \\
{[0.0001]}\end{array}$ & $\begin{array}{c}-0.1461 \\
{[0.1713]}\end{array}$ & $\begin{array}{c}-0.1297 \\
{[0.2245]}\end{array}$ & $\begin{array}{c}-0.0697 \\
{[0.5300]}\end{array}$ & $\begin{array}{c}-0.0839 \\
{[0.4500]}\end{array}$ & $\begin{array}{c}-0.0684 \\
{[0.5380]}\end{array}$ & $\begin{array}{c}-0.0842 \\
{[0.4522]}\end{array}$ \\
\hline Kurtosis & $\begin{array}{l}2.3218 * \\
{[0.0000]}\end{array}$ & $\begin{array}{c}-0.0268 \\
{[0.9002]}\end{array}$ & $\begin{array}{c}-0.0438 \\
{[0.8379]}\end{array}$ & $\begin{array}{c}-0.3516 \\
{[0.1150]}\end{array}$ & $\begin{array}{c}-0.3613 \\
{[0.1053]}\end{array}$ & $\begin{array}{c}-0.3578 \\
{[0.1087]}\end{array}$ & $\begin{array}{c}-0.3621 \\
{[0.1074]}\end{array}$ \\
\hline Normality & $\begin{array}{c}133.7566 * \\
{[0.0000]}\end{array}$ & $\begin{array}{c}1.8978 \\
{[0.3871]}\end{array}$ & $\begin{array}{c}1.5257 \\
{[0.4663]}\end{array}$ & $\begin{array}{c}2.9162 \\
{[0.2326]}\end{array}$ & $\begin{array}{c}3.2349 \\
{[0.1983]}\end{array}$ & $\begin{array}{c}2.9912 \\
{[0.2241]}\end{array}$ & $\begin{array}{c}3.1971 \\
{[0.2021]}\end{array}$ \\
\hline
\end{tabular}

Note: $\quad$ See Table 5.

* denotes 5-percent significance level.

** denotes 10-percent significance level. 
Table A1: Outlier Information

Panel A. Descriptive Statistics

\begin{tabular}{lccccccccccc}
\hline & Obs. & Mean & SD & Q1 & Q2 & Q3 & IQD & $f_{1}$ & $f_{3}$ & $F_{1}$ & $F_{3}$ \\
\hline Quarterly GDP Growth & 533 & 0.8228 & 2.2383 & 0.0784 & 0.8632 & 1.8444 & 1.7660 & -2.5706 & 4.4934 & -5.2196 & 7.1424 \\
\hline
\end{tabular}

Panel B. Frequency of events:

\begin{tabular}{|c|c|c|c|c|}
\hline$y_{t}-$ Mean $\mid>k \cdot \mathrm{SD}$ & $k=2$ & $k=3$ & $k=4$ & $k=\mathbf{5}$ \\
\hline Quarterly GDP Growth & $\begin{array}{l}1932 Q 1 \\
1930 Q 1 \\
1934 Q 1 \\
1935 Q 4 \\
1941 Q 2 \\
1942 Q 4 \\
1934 Q 2 \\
1888 Q 1 \\
1931 Q 3 \\
1876 Q 1 \\
1938 Q 3 \\
1918 Q 4 \\
1946 Q 1 \\
1896 Q 1 \\
1938 Q 1 \\
1934 Q 3 \\
1936 Q 2 \\
1935 Q 1 \\
1897 Q 1 \\
1939 Q 4 \\
1914 Q 4 \\
1921 Q 1 \\
1930 Q 4 \\
192944 \\
1901 Q 1 \\
1932 Q 2 \\
1930 Q 3 \\
1899 Q 1 \\
19202 \\
1931 Q 4 \\
1933 Q 2 \\
1891 Q 3 \\
1920 Q 4 \\
1907 Q 4 \\
1933 Q 1 \\
1933 Q 3 \\
1908 Q 1 \\
1918 Q 2 \\
1879 Q 4 \\
1919 Q 1 \\
1945 Q 4 \\
1933 Q 4 \\
1937 Q 4 \\
1893 Q 3\end{array}$ & $\begin{array}{l}1933 Q 1 \\
1933 Q 3 \\
1908 Q 1 \\
1918 Q 2 \\
1879 Q 4 \\
1919 Q 1 \\
1945 Q 4 \\
1933 Q 4 \\
1945 Q 3 \\
1937 Q 4 \\
1893 Q 3\end{array}$ & 1893Q3 & - \\
\hline
\end{tabular}


Table A2: $\quad$ Outlier Information

\begin{tabular}{|c|c|c|c|}
\hline Date & $y_{t} \leq f_{1}$ & Date & $y_{t} \geq f_{3}$ \\
\hline 1893Q3 & -8.75653 & 1918Q1 & 4.512044 \\
\hline 1937Q4 & -7.44208 & 1915Q4 & 4.575253 \\
\hline 1945Q3 & -7.40205 & 1894Q4 & 4.597397 \\
\hline 1933Q4 & -7.29332 & 1922Q2 & 4.727923 \\
\hline 1945Q4 & -7.14014 & 1924Q4 & 4.981125 \\
\hline 1919Q1 & -6.4836 & 1941Q3 & 5.132264 \\
\hline 1908Q1 & -6.03746 & 1934Q1 & 5.365708 \\
\hline 1933Q1 & -5.99004 & 1935Q4 & 5.402271 \\
\hline 1907Q4 & -5.69925 & 1941Q2 & 5.439613 \\
\hline 1920Q4 & -5.62506 & 1942Q4 & 5.464017 \\
\hline 1931Q4 & -5.26931 & 1934Q2 & 5.573941 \\
\hline 1920Q2 & -5.14992 & 1876Q1 & 5.66863 \\
\hline 1930Q3 & -5.01223 & 1938Q3 & 5.678989 \\
\hline 1932Q2 & -5.00756 & 1936Q2 & 6.081649 \\
\hline 1929Q4 & -4.82265 & 1935Q1 & 6.192347 \\
\hline 1930Q4 & -4.74572 & 1897Q1 & 6.21144 \\
\hline 1921Q1 & -4.65817 & 1939Q4 & 6.263423 \\
\hline 1914Q4 & -4.62649 & 1901Q1 & 6.627313 \\
\hline 1934Q3 & -4.34376 & 1899Q1 & 6.770195 \\
\hline 1938Q1 & -4.31652 & 1933Q2 & 6.961935 \\
\hline 1896Q1 & -4.26888 & 1891Q3 & 7.12518 \\
\hline 1946Q1 & -4.2563 & 1933Q3 & 7.649726 \\
\hline 1918Q4 & -4.10921 & 1918Q2 & 7.818015 \\
\hline 1931Q3 & -4.00449 & 1879Q4 & 7.964976 \\
\hline 1888Q1 & -3.96425 & & \\
\hline 1930Q1 & -3.69189 & & \\
\hline 1932Q1 & -3.67096 & & \\
\hline 1932Q3 & -3.55135 & & \\
\hline 1946Q2 & -3.3992 & & \\
\hline 1893Q4 & -3.3346 & & \\
\hline 1924Q2 & -3.19257 & & \\
\hline 1903Q4 & -3.10203 & & \\
\hline 1940Q1 & -2.93112 & & \\
\hline 1958Q1 & -2.71872 & & \\
\hline
\end{tabular}

\begin{tabular}{|c|c|c|}
\hline Date & $y_{t}$ & $\mid y_{t}-$ Mean $\mid$ \\
\hline 1932Q1 & -3.67096 & 4.493761953 \\
\hline 1930Q1 & -3.69189 & 4.514693847 \\
\hline 1934Q1 & 5.365708 & 4.542908248 \\
\hline 1935Q4 & 5.402271 & 4.579470987 \\
\hline 1941Q2 & 5.439613 & 4.616813279 \\
\hline 1942Q4 & 5.464017 & 4.641217004 \\
\hline 1934Q2 & 5.573941 & 4.751141175 \\
\hline 1888Q1 & -3.96425 & 4.787049654 \\
\hline 1931Q3 & -4.00449 & 4.827290495 \\
\hline 1876Q1 & 5.66863 & 4.84583036 \\
\hline 1938Q3 & 5.678989 & 4.856188877 \\
\hline 1918Q4 & -4.10921 & 4.932006244 \\
\hline 1946Q1 & -4.2563 & 5.079102959 \\
\hline 1896Q1 & -4.26888 & 5.091681146 \\
\hline 1938Q1 & -4.31652 & 5.139317996 \\
\hline 1934Q3 & -4.34376 & 5.16655683 \\
\hline 1936Q2 & 6.081649 & 5.258848876 \\
\hline 1935Q1 & 6.192347 & 5.369547142 \\
\hline 1897Q1 & 6.21144 & 5.388640261 \\
\hline 1939Q4 & 6.263423 & 5.440622852 \\
\hline 1914Q4 & -4.62649 & 5.449290714 \\
\hline 1921Q1 & -4.65817 & 5.480966947 \\
\hline 1930Q4 & -4.74572 & 5.568515057 \\
\hline 1929Q4 & -4.82265 & 5.645451233 \\
\hline 1901Q1 & 6.627313 & 5.8045127 \\
\hline 1932Q2 & -5.00756 & 5.830355026 \\
\hline 1930Q3 & -5.01223 & 5.835033189 \\
\hline 1899Q1 & 6.770195 & 5.947395048 \\
\hline 1920Q2 & -5.14992 & 5.97272059 \\
\hline 1931Q4 & -5.26931 & 6.092113299 \\
\hline 1933Q2 & 6.961935 & 6.139135088 \\
\hline 1891Q3 & 7.12518 & 6.302380216 \\
\hline 1920Q4 & -5.62506 & 6.447861121 \\
\hline 1907Q4 & -5.69925 & 6.52205031 \\
\hline 1933Q1 & -5.99004 & 6.812839527 \\
\hline 1933Q3 & 7.649726 & 6.826925919 \\
\hline 1908Q1 & -6.03746 & 6.860256347 \\
\hline 1918Q2 & 7.818015 & 6.995214788 \\
\hline 1879Q4 & 7.964976 & 7.142176493 \\
\hline 1919Q1 & -6.4836 & 7.306395305 \\
\hline 1945Q4 & -7.14014 & 7.962940516 \\
\hline 1933Q4 & -7.29332 & 8.116115799 \\
\hline 1945Q3 & -7.40205 & 8.22484672 \\
\hline 1937Q4 & -7.44208 & 8.264884475 \\
\hline 1893Q3 & -8.75653 & 9.579333878 \\
\hline
\end{tabular}


Table A3: $\quad$ Outlier Corrected by Franses and Ghijsels (1999) Additive Outlier Detection Quarterly GNP Growth AR(4)-GARCH(1,1)

\begin{tabular}{|c|c|c|c|c|c|}
\hline Location & Date & Value & $k=3$ & Size & Lambda \\
\hline 231 & 1933Q4 & -7.29332 & $※$ & 107.488 & 12.6302 \\
\hline 70 & 1893Q3 & -8.75653 & $※$ & 71.55 & 9.10659 \\
\hline 229 & 1933Q2 & 6.961935 & & 55.6713 & 7.5209 \\
\hline 278 & 1945Q3 & -7.40205 & $※$ & 50.7756 & 7.14605 \\
\hline 247 & 1937Q4 & -7.44208 & $※$ & 49.6185 & 7.29989 \\
\hline 62 & 1891Q3 & 7.12518 & & 44.1903 & 6.79465 \\
\hline 234 & 1934Q3 & -4.34376 & & 33.2772 & 5.19547 \\
\hline 232 & 1934Q1 & 5.365708 & & 33.6301 & 5.40379 \\
\hline 100 & 1901Q1 & 6.627313 & & 32.1756 & 5.32333 \\
\hline 236 & 1935Q1 & 6.192347 & & 32.1198 & 5.43303 \\
\hline 15 & 1879Q4 & 7.964976 & $※$ & 31.5535 & 5.50271 \\
\hline 92 & 1899Q1 & 6.770195 & & 30.9937 & 5.54228 \\
\hline 84 & 1897Q1 & 6.21144 & & 30.7512 & 5.67833 \\
\hline 80 & 1896Q1 & -4.26888 & & 29.7588 & 5.68557 \\
\hline 127 & 1907Q4 & -5.69925 & & 29.1644 & 5.76458 \\
\hline 256 & 1940Q1 & -2.93112 & & 28.9075 & 5.82894 \\
\hline 171 & 1918Q4 & -4.10921 & & 28.5819 & 6.01163 \\
\hline 215 & 1929Q4 & -4.82265 & & 27.7132 & 6.0588 \\
\hline 228 & 1933Q1 & -5.99004 & $※$ & 25.6877 & 5.78083 \\
\hline 195 & 1924Q4 & 4.981125 & & 24.9043 & 5.71216 \\
\hline 169 & 1918Q2 & 7.818015 & $※$ & 22.3191 & 5.31931 \\
\hline 172 & 1919Q1 & -6.4836 & $※$ & 22.4206 & 5.478 \\
\hline 177 & 1920Q2 & -5.14992 & & 22.4714 & 5.65842 \\
\hline 222 & 1931Q3 & -4.00449 & & 20.9017 & 5.43069 \\
\hline 48 & 1888Q1 & -3.96425 & & 20.5925 & 5.45283 \\
\hline 179 & 1920Q4 & -5.62506 & & 18.9762 & 5.18591 \\
\hline 218 & 1930Q3 & -5.01223 & & 18.3766 & 5.18073 \\
\hline 193 & 1924Q2 & -3.19257 & & 17.7098 & 5.05962 \\
\hline 279 & 1945Q4 & -7.14014 & $※$ & 17.2481 & 5.07236 \\
\hline 241 & 1936Q2 & 6.081649 & & 17.2423 & 5.20527 \\
\hline 128 & 1908Q1 & -6.03746 & $※$ & 16.5971 & 5.17551 \\
\hline 250 & 1938Q3 & 5.678989 & & 16.3673 & 5.25823 \\
\hline 155 & 1914Q4 & -4.62649 & & 16.3767 & 5.4062 \\
\hline 255 & 1939Q4 & 6.263423 & & 16.6695 & 5.60622 \\
\hline 223 & 1931Q4 & -5.26931 & & 16.395 & 5.74878 \\
\hline 230 & 1933Q3 & 7.649726 & $※$ & 16.2552 & $5.87036(\mathrm{cv})$ \\
\hline 111 & 1903Q4 & -3.10203 & & 13.8871 & 5.11026 \\
\hline 296 & 1950Q1 & 4.03606 & & 12.0111 & 4.52453 \\
\hline 181 & 1921Q2 & 2.549648 & & 12.0458 & 4.6522 \\
\hline 165 & 1917Q2 & 3.497603 & & 11.3617 & 4.48978 \\
\hline 254 & 1939Q3 & 3.6776 & & 10.9287 & 4.37755 \\
\hline 261 & 1941Q2 & 5.439613 & & 10.4382 & 4.23318 \\
\hline 60 & 1891Q1 & -2.43559 & & 10.2445 & 4.23973 \\
\hline
\end{tabular}




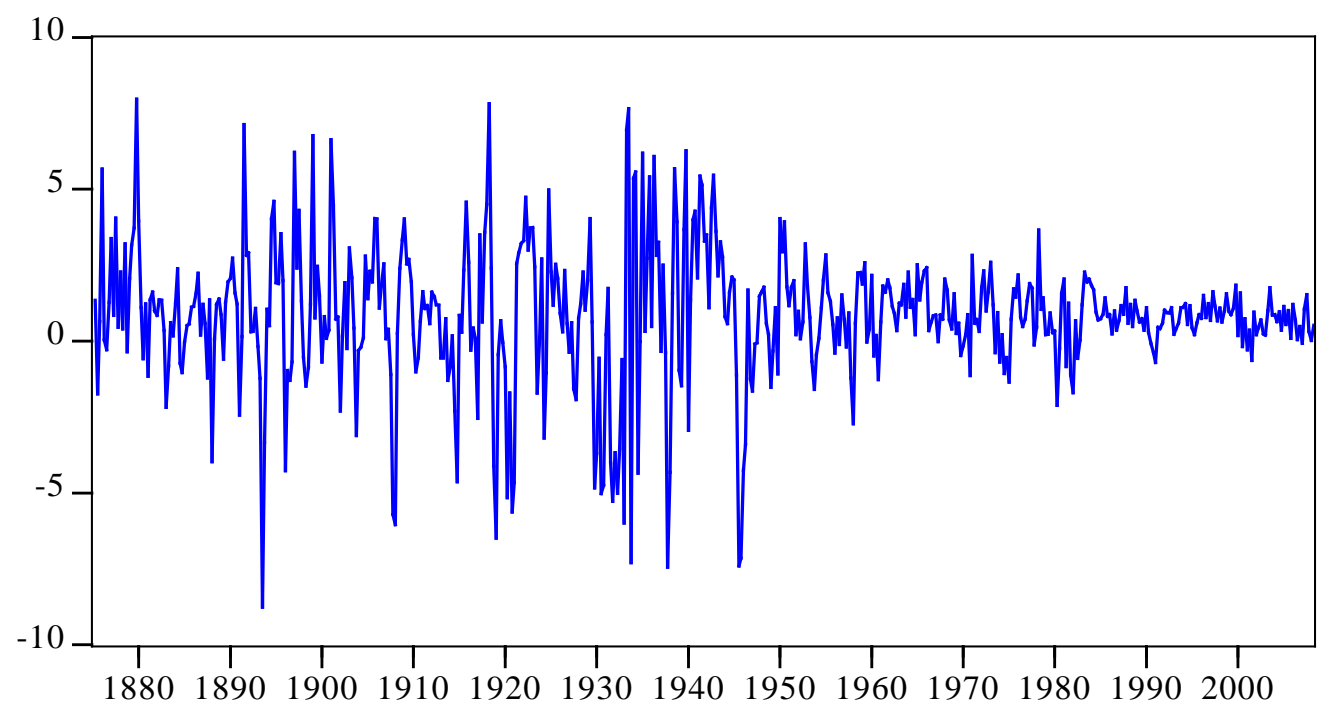

Figure 1. Real GNP Growth Rate 